\title{
The Iceland Palaeomagnetism Database (ICEPMAG)
}

\author{
Justin A. D. Tonti-Filippini ${ }^{1,2^{*}}$ (I) and Maxwell C. Brown ${ }^{1}$
}

\begin{abstract}
The extensive lava piles of Iceland contain a unique record of geomagnetic field variations spanning the past $\sim 16$ Ma. Since the 1950s, palaeomagnetic data have been obtained from over 9400 Icelandic lavas. We have compiled all palaeomagnetic data currently available and developed a publicly accessible database (http://www.icepmag.org). The data within the database are primarily palaeodirections, with a relatively smaller number of palaeointensity data (8936 entries contain direction only, 218 intensity only, and 337 both direction and intensity). In addition, the database contains a wide range of metadata, including geochronological information, site details, and laboratory methods. The search interface of the database allows users to search for data using a range of customisable filters (e.g. by publication, geological age, location, laboratory method, palaeomagnetic statistics) and to quickly visualise and download the matching search results. The data within the database have significant potential for understanding long-term palaeomagnetic field variations at high latitude, the behaviour of excursions and reversals, and geological mapping on Iceland.
\end{abstract}

Keywords: Palaeomagnetism, Geomagnetism, Database, Iceland, ICEPMAG

\section{Introduction}

Igneous rocks, sediments, and archaeological materials have the capacity to preserve a record of Earth's palaeomagnetic field. Compilations of palaeomagnetic data are vital for understanding the global behaviour of the palaeomagnetic field and its long-term evolution. The value of palaeomagnetic databases has been recognised since the 1960s, as researchers began to compile databases for different purposes, driven by specific scientific questions or a general desire to catalogue all available data. Modern databases, such as the GPMDB (McElhinny and Lock 1996; Pisarevsky et al. 2018), GEOMAGIA50 (Korhonen et al. 2008; Brown et al. 2015), and MagIC (Jarboe et al. 2012), continue to compile legacy and new data. These databases have the potential to improve reconstructions and global models of the geomagnetic field, but only if the data are accompanied by detailed information that allows researchers to make informed assessments about

\footnotetext{
*Correspondence: jad3@hi.is

${ }^{1}$ Institute of Earth Sciences, University of Iceland, Sturlugata 7

101 Reykjavík, Iceland

Full list of author information is available at the end of the article
}

the reliability of the data. Modelling of the geomagnetic field on different timescales, for example, relies on such databases, and models based on updated global datasets are likely to surpass their predecessors and offer new insights into deep Earth processes (Johnson and McFadden 2015).

The issue of careful storage and selection of data is particularly relevant for Iceland, where lavas suitable for palaeomagnetic studies are abundant. Lavas provide our best opportunity to recover the past behaviour of the magnetic field beyond the timescales regularly covered by marine sedimentary cores. Iceland, due to its proximity to a mantle plume and an actively spreading tectonic plate boundary (Fig. 1), has erupted prolific stacks of lava flows over the past 16 million years $(\mathrm{Ma})(\mathrm{McDou}-$ gall et al. 1984) and experienced minimal continental drift and tectonic rotation or tilting, with generally $<10^{\circ}$ of regional tilt (Kristjánsson 2002). In many places, the lava piles have been uplifted and exposed in deep vertical sequences as a result of glacial and hydraulic action. Iceland's unique geological setting, combined with low vegetation cover and a sparse population, provides excellent opportunities to study long sequences of lavas for 


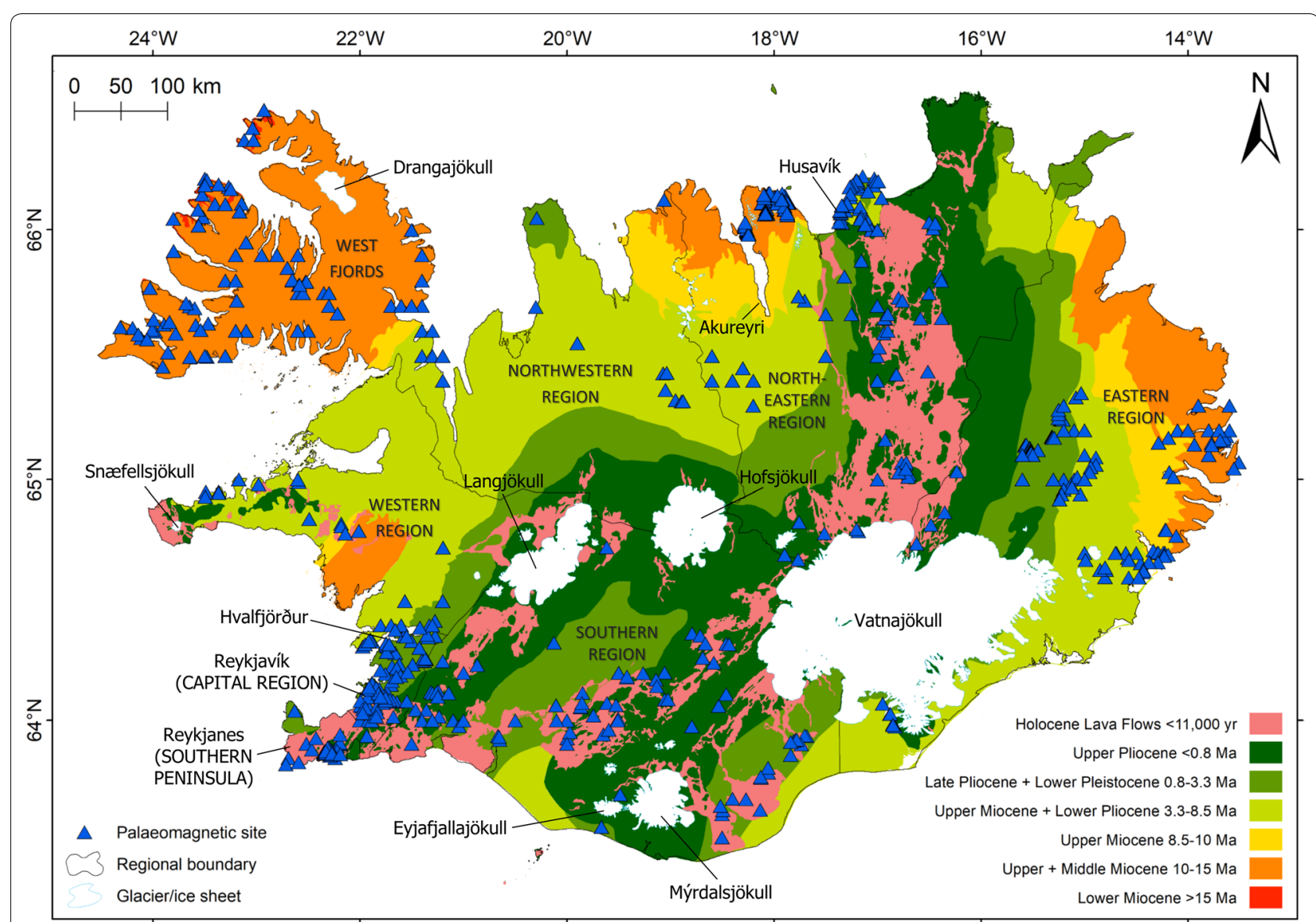

Fig. 1 Map of ICEPMAG sites with bedrock geology and regional boundaries. All ICEPMAG sampling site locations. Regional boundaries defined by country subdivision code ISO 3166-2:2013. Tectonic geology map adapted from Jóhannesson and Sæmundsson (2009) based on data publicly available from The Icelandic Institute of Natural History (open license: http://www.ni.is/rannsoknir/landupplysingar/skilmalar)

mapping purposes and for revealing the evolution of the palaeomagnetic field through statistical analyses (e.g. Kristjánsson 2013; Suttie et al. 2015). Iceland is the only location with an almost continuous history of volcanism over $0-16 \mathrm{Ma}$, particularly beyond $5 \mathrm{Ma}$, and can resolve long time series of palaeomagnetic variations. The country's position, between $63^{\circ}$ and $67^{\circ}$ latitude, also makes it one of very few high-latitude locations where lavas suitable for palaeomagnetic study are exposed, and is important for understanding geomagnetic field behaviour at high latitudes.

In this paper, we describe the construction and functionality of a newly developed palaeomagnetic database for Iceland, ICEPMAG, which compiles all palaeomagnetic data published from Icelandic lavas. Vital information can be lost as researchers retire and studies age, so an emphasis was placed on capturing all available metadata and enriching existing compilations where possible. There are a significant amount of data from Iceland which have not previously been compiled into a comprehensive and consistent format. The construction of ICEPMAG is important for preserving the legacy of Iceland's unique and extensive palaeomagnetic dataset and is in line with other recent efforts to produce large regional compilations by combining new palaeomagnetic data with legacy data, such as those for the North and South West USA, Mexico, Hawaii, South Pacific, and Reunion (see Johnson and McFadden 2015).

ICEPMAG was designed to be a useful tool for palaeomagnetists to carry out research on variations in the palaeomagnetic field over the past $16 \mathrm{Ma}$, including longterm trends in palaeosecular variation, the behaviour of reversals and excursions, and the variations of natural remanent magnetisation (NRM) as a measure of relative intensity through time or with virtual geomagnetic pole (VGP) latitude. The database will also be useful for geologists working on Iceland, e.g. for identifying reversal boundaries which can be used in magnetostratigraphy mapping allowing correlation of lavas across hillsides and valleys. ICEPMAG will be an important reference and 
repository for future work carried out in the University of Iceland's recently refurbished palaeomagnetic laboratory.

This paper contains summaries of the history of palaeomagnetism in Iceland, global palaeomagnetic databases, and the past and present uses of Icelandic palaeomagnetic data; descriptions of the design principles and methodology behind the construction of the ICEPMAG database; as well as an overview of the data in the database and its functionality, and issues, potential uses and future work related to Icelandic data.

\section{Background}

\section{Palaeomagnetism in Iceland}

Palaeomagnetic research in Iceland has contributed to a number of geoscientific discoveries. We briefly note the most significant of these and refer the reader to Kristjánsson (1982, 1993, 2008) for more details. Discovery of reversely magnetised rocks early in the twentieth century fuelled much speculation about the past nature of the geomagnetic field and drew significant attention to the field of palaeomagnetism.

The first detailed study on Icelandic lavas to investigate geomagnetic field reversals was carried out by Jan Hospers (1951), a PhD candidate from the University of Cambridge at the time. Hospers published his results with the assistance of Sir Ronald Fisher, who had devised a method of spherical statistics (Fisher 1953) that enabled Hospers to better display and analyse his results through the use of VGPs. Data from Hospers's Icelandic samples, which Fisher used as an example when publishing his method, contributed to many accepting the legitimacy of geomagnetic field reversals (Frankel 1987). Hospers (1953) interpreted his own measurements to suggest that 'taken over periods of several thousands of years the magnetic pole centres on the geographic pole'-an early formulation of the geocentric axial dipole (GAD) hypothesis (see Merrill and McElhinny 1983).

Palaeomagnetic work was continued by a number of Icelandic scientists who contributed greatly to the field. Trausti Einarsson and Porbjörn Sigurgeirsson used a field compass (Einarsson 1957) to measure the polarity of thousands of lava flows across Iceland while building up maps of polarity zones, intending to use the results to assist in geological age determination (Kristjánsson 1982). This technique is similar to the geochronological approach later used to construct the geomagnetic polarity time scale (GPTS) (see Ogg 2012). Sigurgeirsson collaborated with Ari Brynjólfsson (1957) to use alternating field (AF) demagnetisation to remove viscous overprints in Icelandic lavas, probably the first demonstration that a stable primary remanence direction could be isolated with this technique (Kristjánsson 1993). The innovative technique enabled the first detailed study of intermediate and transitional palaeomagnetic directions, illustrating the 'R3-N3' reversal recorded by the lavas in Hvalförður, western Iceland (Sigurgeirsson 1957).

A number of studies published in the 1970s and early 1980s produced very large datasets from thousands of Icelandic lava flows, e.g. Watkins and Walker (1977) in eastern Iceland, Watkins et al. (1977) in Borgarfjörður (western Iceland), and McDougall et al. (1984) in the Westfjords. Data from these large studies contributed to some promising developments in the applications of Iceland palaeomagnetism (e.g. Kristjánsson and McDougall 1982). The collection from eastern Iceland, for which fieldwork was carried out over 1964-1965, generated several papers and theses and was, at the time, probably the largest palaeomagnetic collection from anywhere in the world and 'the most comprehensive source of data from a single region on long-term $(0.1-10 \mathrm{Myr})$ variations of the geomagnetic field' (Kristjánsson 1985c). The results from the campaign included confirmation of more than sixty reversals between 2-13 Ma (Dagley et al. 1967), significantly more than the number derived from marine sediment cores, and the application of reversals in stratigraphy across $10 \mathrm{~km}$ or more (Kristjánsson 2008). Dagley and Wilson (1971), and also Wilson et al. (1972), highlighted the benefits of sampling a large number of lavas in a single region and statistically analysing their remanence intensities as a function of VGP latitude. Kristjánsson and Jóhannesson (1989) analysed directions from $\sim 4000$ Icelandic lava flows and found that the magnitude of total VGP dispersion has decreased significantly over the past $15 \mathrm{Ma}$, and that the geomagnetic field's polarity 'had no discernible effect on its mean configuration or directional dispersion'.

By far, the most significant individual contributor to palaeomagnetism in Iceland since the 1960s has been Leó Kristjánsson, whose body of work spans over 50 years (Kristjánsson 1968; Kristjánsson and Jónsson 2017)—see Kristjánsson (2013) for a general summary of his work.

Palaeomagnetism on Icelandic lavas has been primarily used as a stratigraphic mapping aid. Hospers initially came to Iceland with the hope of using differences in the strength of magnetisation to correlate the lavas (Frankel 1987). Generally, Icelandic lavas are strongly magnetised with an easily isolated component of primary origin, containing negligible or low viscous remanent magnetisation (VRM), and are not commonly affected by chemical weathering or lightning impacts (Kristjánsson 2013). These characteristics, combined with good exposure, mean that sections of tens of lavas or more can be correlated across hillsides to make composites of hundreds of lavas. Frequent reversal boundaries provide important markers for geological mapping and allow lavas to be traced across several kilometres (see Kristjánsson 
2009). Samples across individual lavas separated by tens of metres to several kilometres can also yield consistent directions (e.g. Kristjánsson and Sigurgeirsson 1993; Kristjánsson and Audunsson 2007; Kristjánsson 2016).

Icelandic lavas have continued to be used to improve controls for local stratigraphic mapping and the resolution of the GPTS (e.g. Kristjánsson et al. 1980; Kristjánsson and Jóhannesson 1996; Helgason and Duncan 2001; Kristjánsson et al. 2004), as well as to further characterise palaeomagnetic field reversals (e.g. Kristjánsson and Sigurgeirsson 1993; Goguitchaichvili et al. 1999a; Brown et al. 2006) and excursions (e.g. Levi et al. 1990; Kristjánsson 1999; Udagawa et al. 1999; Jicha et al. 2011).

Palaeomagnetic techniques have also been used to understand the tectonic history of the island (Jancin 2010; Horst et al. 2018; Titus et al. 2018; Young et al. 2018), e.g. palaeomagnetic directions combined with structural data have been used to quantify varying clockwise rotation with distance from the Husavík-Flatey fault in northern Iceland (Titus et al. 2018).

Comparatively, few studies have investigated absolute palaeointensity of Icelandic lavas, which have generally targeted the younger lavas/neo-volcanic zone in the proximity of Iceland's central spreading ridge (this is discussed further in "Palaeointensity data" section). However, several studies sought to investigate the absolute intensity of the field during reversals (e.g. Shaw 1975; Tanaka et al. 1995; Goguitchaichvili et al. 1999a, b; Brown et al. 2006).

Despite access to abundant material suitable for palaeomagnetism, there are some caveats to research in Iceland. Volcanism can be sporadic, with an average time interval between flows of $\sim 10^{4}$ years, and there are often significant hiatuses within sections, perhaps up to $10^{5}$ years, meaning that major excursions and transitional events are not always recorded (Kristjánsson 2002). In some areas, stratigraphy is complicated by lavas coming from different sources, i.e. rift zones and central volcanoes. Recent (i.e. $<2 \mathrm{Ma}$ ) stratigraphy is also complicated by glaciation and erosion, and the effects of local anomalies, deformation, and tectonic tilting can be difficult to detect, possibly influencing the reliability of palaeodirectional determinations (see Kristjánsson and Jónsson 2007). Alteration and low potassium and argon contents in Icelandic lavas can impact the accuracy of radiometric dating efforts which may have uncertainties in the order of $5 \%$ (Kristjánsson 2002).

\section{Global palaeomagnetic databases}

Researchers have been compiling global palaeomagnetic databases since the late 1960s, when early 'pole catalogues' were developed to combine palaeomagnetic data (i.e. palaeodirections) with radiometric dating information (e.g. Khramov 1971, 1976; Hicken 1972; Irving et al. 1976; McElhinny and Cowley 1977). Pole catalogues facilitated the correlation of global data and enabled testing of ideas about the past behaviour of the geomagnetic field, e.g. the GAD hypothesis, polar wander, and geomagnetic polarity reversals.

From the late 1980s onwards, with the advent of modern computing, digital relational databases were devised to link palaeomagnetic data with other geoscientific data (e.g. Pesonen and Torsvik 1989; Barton 1991; McElhinny and Lock 1991; Tanaka and Kono 1994). Prior to the International Association of Geomagnetism and Aeronomy (IAGA) providing downloadable compilations, there were no formal archives for palaeomagnetic data outside of internal library databases (see Tauxe et al. 2016). IAGA's Global Paleomagnetic Database (GPMDB), originally created by McElhinny and Lock (1996), is continually updated (see Pisarevsky 2005; Pisarevsky et al. 2018).

Over the past 30-40 years there have been advances in the way palaeomagnetic data are measured and analysed (see Johnson and McFadden 2015). In 2003, the Magnetics Information Consortium (MagIC) identified a need to integrate existing databases, supplemented with more detailed information and data (i.e. the measurements themselves), 'into a single unified data structure' (Tauxe et al. 2003). MagIC developed an online database for rock and palaeomagnetic data which incorporated flexible metadata structures and an adaptable web portal. The MagIC database enables researchers to make their data quickly and more widely accessible, and available in greater detail than is permitted within the space limitations of scientific journal articles. MagIC also sought to compile and archive legacy data into a consistent format (Koppers et al. 2005).

\section{Icelandic data in global analyses}

Palaeomagnetic data from Iceland have played a significant role in various global compilations which sought to understand the evolution of the palaeomagnetic field. For example, in the compilation of Johnson and Constable (1995) for studies of palaeosecular variation, Iceland contributed $\sim 15 \%$ of the global data. Icelandic data have been particularly important for studying the global behaviour of geomagnetic field reversals and transitional field states: in the compilation of Love (1998), which investigated transitional pole paths during geomagnetic reversals, Icelandic lavas provided $\sim 75 \%$ of the data from transitional events and were the 'most significant contributors' to identification of preferred longitudes for transitional poles (Constable 2001). In a compilation of palaeointensity data by Perrin and Schnepp (2004), Iceland contributed the 'largest regional dataset' and most 
of the data from locations in the Atlantic Ocean. A more recent analysis of compilations from Cenozoic large igneous provinces (Suttie et al. 2015) included data from 390 Icelandic flows, the largest regional compilation in the study and $\sim 37 \%$ of the total dataset.

Icelandic data have the potential to be useful in palaeosecular variation (PSV) and time-averaged field (TAF) studies. The PSVRL database, described by McElhinny and McFadden (1997), has been one of the main sources for PSV and TAF studies over the past two decades (Johnson and McFadden 2015) and contains data from 3719 sites in the age range $0-5 \mathrm{Ma}$. Ten studies from Iceland were included in PSVRL, with data from 748 sites ( $\sim 20 \%$ of the dataset) meeting their applied quality criteria. In PSVRL and similar databases, such as those described by Quidelleur et al. (1994) and Johnson and Constable (1996), Icelandic data dominate the latitude band $60^{\circ}-69.9^{\circ}$ and sites with VGPs of reverse polarity (Kelly and Gubbins 1997).

Johnson and McFadden (2015) advocate for more stringent quality criteria and collection of new data for studies of PSV, as it is considered that early (i.e. pre-1980s) palaeomagnetic studies, which generally aimed to test fundamental ideas such as magnetic polarity and the GAD hypothesis, produced data with a coverage and quality inadequate for what is required from datasets today. This view is exemplified by the recent PSV10 compilation (Cromwell et al. 2018), which sought to include 'all high-quality paleodirectional data' from volcanic units in the $0-10 \mathrm{Ma}$ age range. PSV10 includes 2401 sites globally, with the vast majority of sites (93\%) falling in the age range $0-5 \mathrm{Ma}$ and most (1753 sites or 73\%) being of normal polarity. Iceland has produced many data from 5-10 $\mathrm{Ma}$ (and of reverse polarity), but they appear to have been excluded from PSV10 due to the requirements for the application of modern magnetic cleaning methods or, more specifically, that 'principal component analysis' (PCA) was applied to determine specimen directions, i.e. the 'DC-4' or 'DC-5' protocol, using the classification of McElhinny and McFadden (2000). Studies were also excluded from the compilation if 'demagnetization methods were not clearly stated' or they specifically targeted transitional events (Cromwell et al. 2018). Only two Icelandic studies (Udagawa et al. 1999; Døssing et al. 2016), with samples from 62 sites within a narrow age window $(0.6-3.1 \mathrm{Ma})$, were included in the PSV10 dataset although available data span back to $16 \mathrm{Ma}$ (Kristjánsson 2013).

Since the early 1980s, studies in Iceland have largely utilised a magnetic cleaning method which is not captured in the 'DC' classification codes, where specimens are only demagnetised 'as far as necessary to confirm the presence of a stable remanence direction' (Kristjánsson and Jónsson 2007). The demagnetising step which results in the smallest $\alpha_{95}$ value is then selected for the site's mean direction (e.g. Kristiánsson 2016). Justification for the use of the ' $\alpha_{95}$-minimising' method is discussed in Kristjánsson and Jónsson (2007), which considers that '...there is no worthwhile gain in quality by applying further demagnetization' and finds no significant difference between studies of the same lavas where this method and more detailed treatment/analysis (i.e. PCA) have been applied. Similarly, Kristjánsson (2013) suggests, for Icelandic samples, a 'remanence direction isolated at $10 \mathrm{mT}$ AF treatment is generally almost unchanged after treatment at 15, 20, 25 and $30 \mathrm{mT}$, and the 'use of extensive demagnetising procedures such as those that have been developed for paleomagnetic materials of inferior quality from elsewhere, therefore serves no practical purpose'. The issue of magnetic cleaning and removal of secondary overprints was also addressed during the compilation of the PSVRL database: McElhinny and McFadden (1997) listed a number of studies recommended for replacement, and it is worth noting that no Icelandic studies were included in this list.

The paucity of PSV10 data for 5-10 Ma (only 166 sites) could be rectified somewhat if Icelandic data were considered to be of adequate quality. For example, the study detailed in Kristjánsson et al. (2004) includes measurements from 319 lavas across the 5-9 Ma age range. It is intended that searching for and retrieving information with specific metadata (e.g. by specimen demagnetisation method), to address questions like this, will be made significantly easier by the creation of the ICEPMAG database.

\section{Previous Icelandic compilations}

The largest (previously existing) compilation of Icelandic data is described by Kristjánsson (2013) and consists of information from over 5800 Icelandic lava flows: $~ 5200$ were considered suitable for statistical analyses, with an additional $\sim 600$ not used in all analyses because of their lack of NRM intensity information or large directional uncertainties (i.e. $95 \%$ confidence radii $\alpha_{95}>12^{\circ}$ ). The results from $\sim 80$ sites in this compilation were never formally published. The dataset described by Kristjánsson (2013) contains ten data fields and some limited metadata in an unpublished notes file.

\section{Construction of the database Design principles}

While ICEPMAG is intended to be used by palaeomagnetists assessing Icelandic data and building their own compilations, it was constructed with the needs of the wider Earth science community in mind, e.g. geologists and other Earth scientists working in Iceland, to aid in 
geological mapping projects or other volcanological applications. We wanted ICEPMAG users to be able to quickly search for and visualise data that may be relevant to their own work (e.g. viewing study locations by age) and make their own judgements about the quality and usefulness of those data. It was important that the database could be easily accessed and understood by first-time users.

To achieve this, ICEPMAG follows the design principles of GEOMAGIA50 (Korhonen et al. 2008; Brown et al. 2015), which allows users to search for and access data across multiple studies. The database is stored on a MySQL server which allows for the database to be queried with specific 'statements' and returns a flexible output that can be adapted and displayed by external scripting (i.e. the search results). Users access the database through a web query form (http://icepmag.org/ query.php), which sends user queries to the SQL server. The results from the query are sent back to the website and printed to a results page through interpretive scripting which also generates downloadable files and graphics. No software needs to be installed, so updates can be made regularly without requiring users to download new software.

ICEPMAG was designed to allow transfer of data to the MagIC database to remedy the lack of Icelandic studies there. At the time of writing, MagIC contains only 27 studies from Iceland with data and some limited metadata from 2634 sites. Wherever possible, ICEPMAG has incorporated the vocabulary of MagIC's data model (v3.0) to enable a seamless transfer. ICEPMAG follows the site-sample-specimen hierarchy as utilised by MagIC and described by Butler (1992), where a site represents an individual unit or bed of an igneous complex (e.g. a lava flow or dike) from which samples were taken and cut into individual specimens for palaeomagnetic measurements. ICEPMAG stores data at the site level; this approach required a trade-off between accessibility and the level of detail stored in the database. ICEPMAG cannot store data to the level of detail that MagIC can, but retrieval and visualisation of Icelandic data are straightforward and tailored towards Iceland.

Another key principle in the construction of ICEPMAG is the use of 'master' and 'relational' tables (Additional file 1: Tables S1-S16). Instead of storing long text strings in the master table, some of the data fields list integer IDs which reference separate relational tables, e.g. region names with special Icelandic characters (Table 1). This structure allows for more detailed descriptions and complex text to be stored in relational tables, rather than in the master table. This approach is particularly useful
Table 1 Relational table for Icelandic region names

\begin{tabular}{lll}
\hline ID & Region (English) & Region (Icelandic) \\
\hline 1 & Capital Region & Höfuðborgarsvæði \\
2 & Southern Peninsula & Suðurnes \\
3 & Western Region & Vesturland \\
4 & Westfjords & Vestfirðir \\
5 & Northwestern Region & Norðurland vestra \\
6 & Northeastern Region & Norðurland eystra \\
7 & Eastern Region & Austurland \\
8 & Southern Region & Suðurland \\
\hline
\end{tabular}

Only the IDs in the first column are stored in the master table

for lists of things that are recurrent, e.g. the laboratory method codes defined in MagIC's data model.

\section{Methodology}

The first step in the construction of the database was to build a source library from an extensive literature search, utilising websites such as Google Scholar (https://schol ar.google.com/), ISI Web of Science (http://webofknowl edge.com/), and MagIC (https://www2.earthref.org/ $\mathrm{MagIC/}$ ). This process was aided significantly by an online paper archive (https://notendur.hi.is/leo/) compiled by Leó Kristjánsson, who also provided hard copies of several papers unavailable on the Internet. This process identified 79 papers containing original site-level palaeomagnetic data (averaged site-mean direction and/or intensity from a lava flow) from 9491 Icelandic sites (as of March 2019). Most of the papers were published in peer-reviewed journal articles, with two contributions from academic theses. Of these papers, Leó Kristjánsson is the lead author of 25 and co-author of a further 9 , contributing palaeomagnetic directions from over 6339 lavas. Not all of the papers were widely available; 19 do not possess permanent digital object identifier (DOI) links and several were only available in hard copies which are not globally distributed.

While building up the source library, data and metadata types common to all papers, and potentially useful to future users, were identified. These were used to select appropriate fields for the ICEPMAG database (see "Data fields" section). Relevant fields were also drawn from the GEOMAGIA50 and MagIC databases, with future uploads to the MagIC database in mind. Selected data fields were then used to set up master and relational tables using the MySQL database, the structure of which was based on GEOMAGIA50. The master table contains 70 data fields, where each row represents an individual site. Fifteen of the data fields in the master table do not contain numerical data or text, but instead list integer ID codes which reference relational tables (discussed above). 
The next step involved progressing through the source library study by study and populating the master and relational tables with data and metadata. This was achieved by: (1) copying data directly from published spreadsheets, the MagIC database, or the compilation described by Kristjánsson (2013), if available; (2) translating tables from a published PDF documents; or (3) typing out data manually if a PDF could not be read digitally. If copied from existing compilations, data were crosschecked against the original source material.

Papers were read through, and key metadata, if not copied directly from existing entries in MagIC, were extracted from the text and/or figures in each paper, e.g. location and region names, sampling and orientation methods, laboratory protocols and statistical techniques used. Geographic coordinates (i.e. site latitude and longitude) are occasionally given in papers, but often the coordinates needed to be inferred from published location maps.

To allow the user access to the database, a web query form was designed for ICEPMAG's front-end. This query form was based on the form used for GEOMAGIA50. Fields considered useful for searching and filtering data were used to construct the form, which utilises both HTML and PHP scripting. A number of output and download options were included in the form (see "Query form" section). Interpretive PHP scripting, also adapted from GEOMAGIA50, used to transfer user queries from the query form to the server side MySQL database and return data back to a results page, so users can visualise and download data (see "Results page" section).

The final step in the construction process was to design additional functionality and webpages for the website, including a searchable list of included studies, news and updates related to the database, statistics on database usage, as well as relevant credits and links to other databases.

\section{Data fields}

This section describes the types of information stored across ICEPMAG's 70 data fields (Additional file 1: Table S1). As with GEOMAGIA50, all data are provided at the site level, i.e. data are from individual lava flows (as noted in "Design principles" section).

\section{Palaeomagnetic data and metadata}

Palaeomagnetic data are split into directional and palaeointensity data and associated uncertainties. Site directional data are reported in both geographic and tilt-corrected coordinates. These fields include declination, inclination, corresponding VGP latitude and longitude (calculated from tilt-corrected and uncorrected directions, if provided), directional polarity (e.g. normal or reverse), as well as statistical parameters such as $95 \%$ confidence limit $\left(\alpha_{95}\right)$, angular standard deviation $\left(\theta_{63}\right)$, resultant Fisher vector $(\mathrm{R})$, dispersion parameter $(k)$, parallel latitude uncertainty (DP) and meridian uncertainty (DM). Also included are various metadata relating to the direction calculation such as demagnetisation type (e.g. $\mathrm{AF}$ or thermal) and peak demagnetisation step (for AF), number of samples/specimens used, type of specimen direction calculation (e.g. principal component analysis), sample direction averaging method (e.g. averaged declination and inclination), site direction averaging method (e.g. mean calculated with Fisherian statistics) and magnitude of tilt correction (if applied). To describe the method used by Leó Kristjánsson for many entries in ICEPMAG (as discussed in "Icelandic data in global analyses" section), we have listed the specimen direction calculation type as 'LP-DC2' (with respect to the method codes in MagIC's vocabulary) and the site direction averaging method as 'a95 min' (i.e. the mean direction at the AF step which produces the smallest $\alpha_{95}$ is selected).

\section{Palaeointensity data and metadata}

These fields include data obtained from palaeointensity determinations, such as site mean palaeointensity and uncertainty (usually standard deviation), and corresponding dipole moment calculations for VDM and VADM and their uncertainties. Also included are various metadata such as palaeointensity method used (see "Palaeointensity data" section for an overview of the palaeointensity methods included in the database), number of samples/specimens used, and type of alteration check. Fields for anisotropy and cooling rate corrections were not added at this time as no studies reported this information.

\section{Magnetisation and susceptibility data and metadata}

These fields include data such as mass or volume normalised average magnetisation (often listed as $J_{\text {NRM }}$ or $J_{100}$ in publications, denoting the NRM intensity or intensity after $10 \mathrm{mT}$ AF demagnetisation) and associated uncertainty, Koenigsberger ratio and average bulk susceptibility, as well as metadata for the demagnetisation step at which remanence is reported (Leó Kristjánsson commonly reported remanence intensity at $J_{100}$ ).

\section{Sampling metadata}

These fields include site name (the ID of an individual flow), sampling type (e.g. portable drill or hand samples), height (above arbitrary point, e.g. base of profile) and/or elevation (above sea level), number of samples collected and sample names (if listed), as well as specimen type (e.g. $2.5 \mathrm{~cm}$ diameter cores cut into $2-2.2 \mathrm{~cm}$ lengths), 
number of measured specimens per sample and specimen names (if listed).

\section{Age data and metadata}

These fields include estimated age and associated error, and/or upper and lower bounds on age estimates, as well as metadata about the employed dating method, such as geological estimate or radiometric dating (see "Locations and ages of palaeomagnetic sites" section for an overview of dating methods used on Iceland).

\section{Geological data and metadata}

These fields contain information about geology of the site including bedding orientation (dip and dip direction), geologic class (e.g. igneous), and geologic type (e.g. lava or volcanic dike).

\section{Geographic data and metadata}

These data fields include coordinates for site latitude and longitude, and metadata such as location/area name and wider region name.

\section{Study information}

The reference ID field links to a relational table containing study metadata such as authors, title, year, publication name, as well as DOI and MagIC links (if they exist).

\section{User interface \\ Query form}

ICEPMAG's database can be accessed through an online query form which allows users to search for and retrieve data based on a range of customisable constraints (Fig. 2):

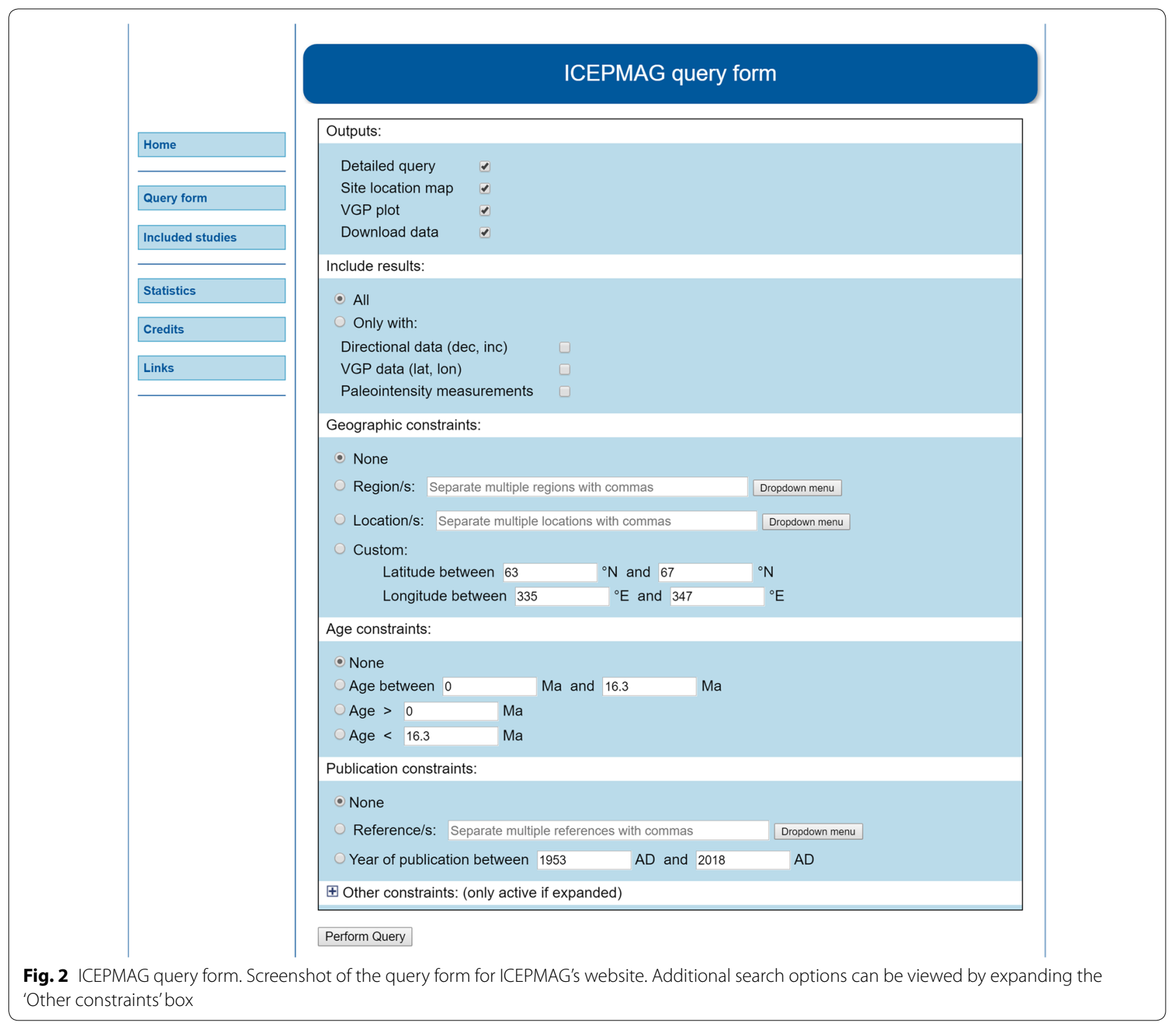




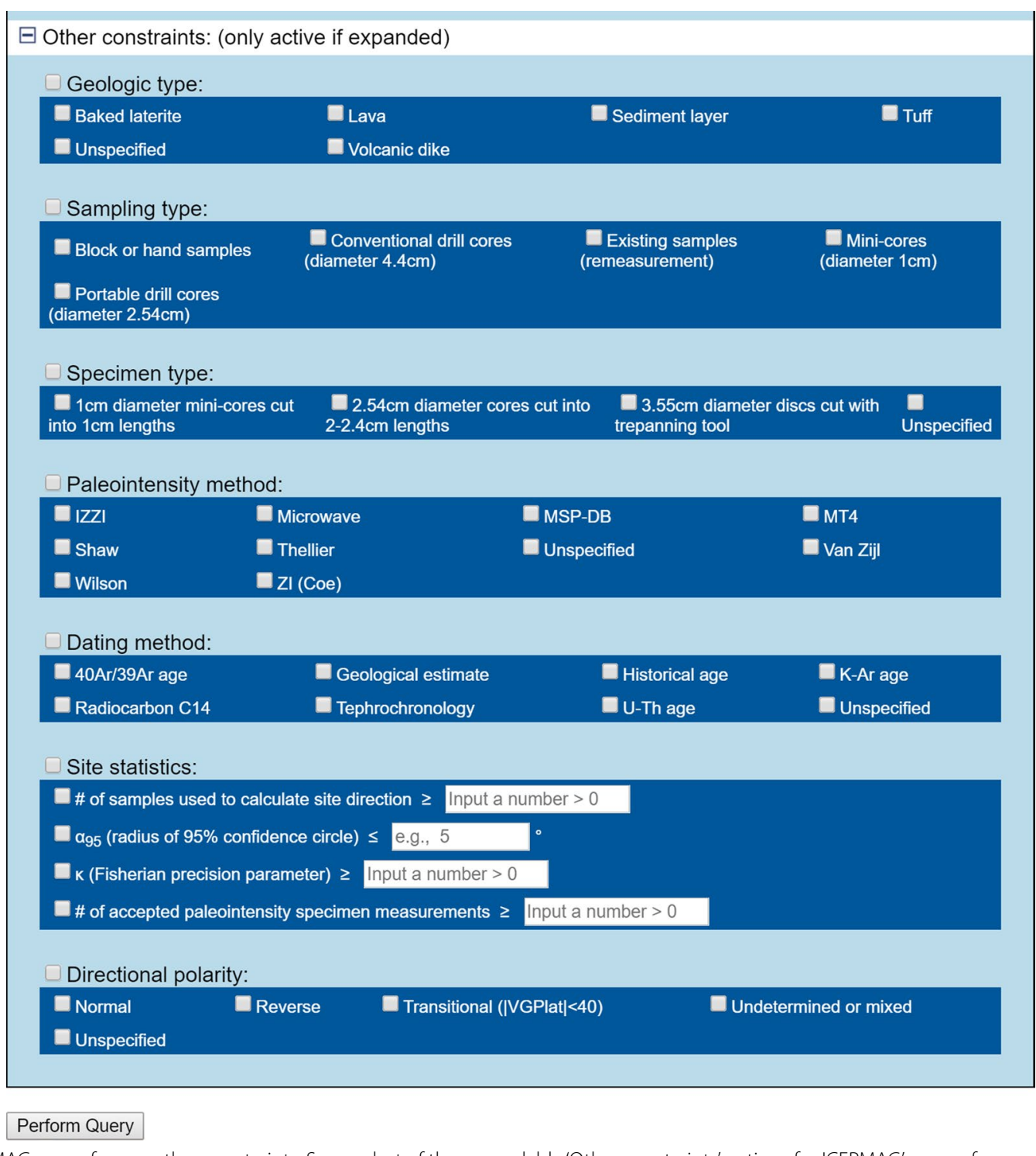

Fig. 3 ICEPMAG query form —other constraints. Screenshot of the expandable 'Other constraints' options for ICEPMAG's query form

- Optional outputs, including the level of detail in the HTML results table, an interactive site location map, as well as a downloadable VGP plot and a CSV file containing data for the search results;

- A filter for the results to select only sites which report directional data, VGP data and/or palaeointensity measurements;

- Geographic constraints, such as a selected region or location within Iceland (can select multiple options), or between specified coordinates;

- Age constraints, which allow the user to select data from sites estimated to be older than, younger than, or in between certain ages;
- Publication constraints, which allow for specific references (by author and year) to be selected, or to search by year of publication;

- Other constraints (Fig. 3), which allow the user to search for results using various metadata such as geologic type, sampling type, specimen type, palaeointensity method, dating method, site statistics, and directional polarity.

The advanced search options allow the user to quickly set up search parameters and return different datasets, or search for studies containing particular types of data or methods, e.g. the user may want to remove studies with a small number of samples per flow, such as the 


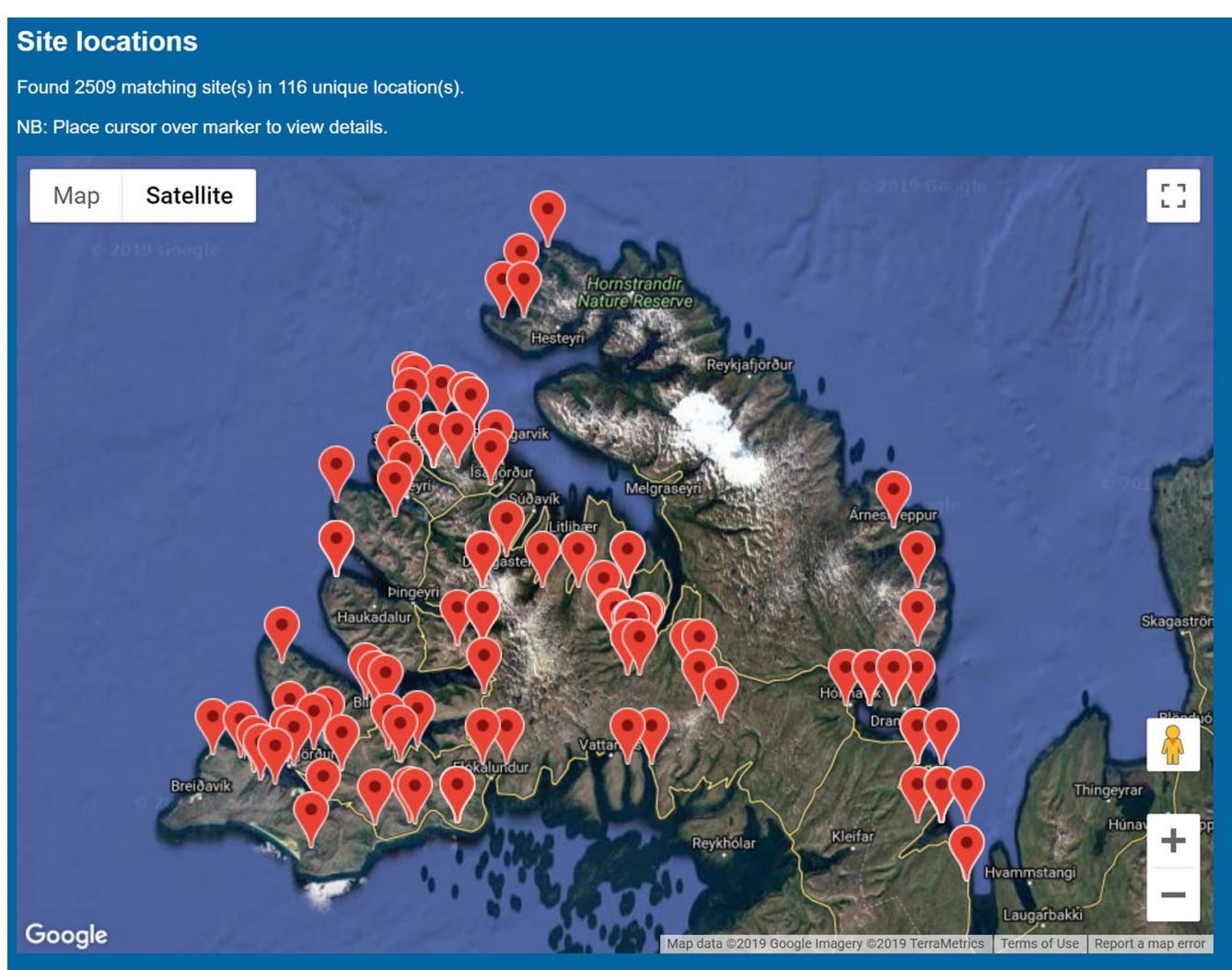

Fig. 4 Example site location map. Screenshot of an interactive location map generated by an ICEPMAG query (all sites in the Westfjords region)

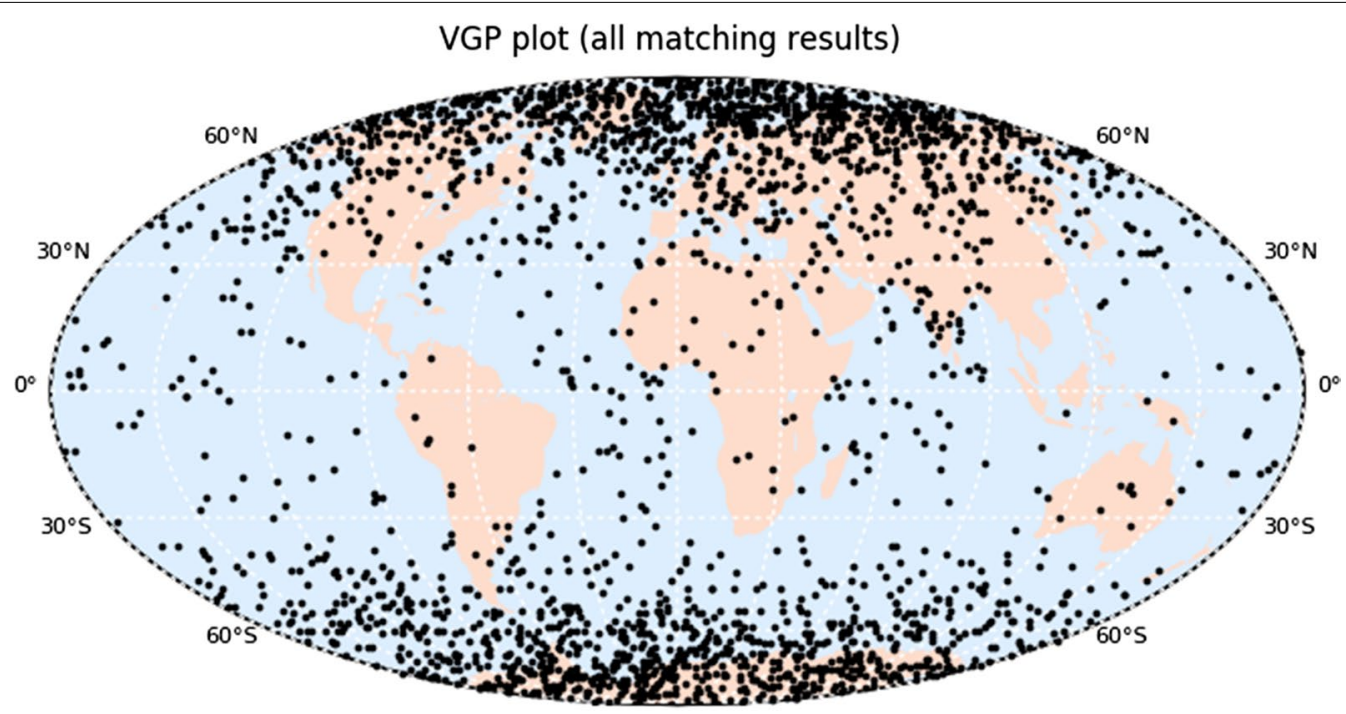

Created using ICEPMAG v1.0 on 20 Jan 2019

Fig. 5 Example of VGP plot. Screenshot of a VGP plot generated by an ICEPMAG query (all published VGP data from the Westfjords)

Watkins and Walker (1977) study in the Eastern Region in which only two samples per flow were collected, or specifically target or exclude studies of dikes (e.g. Piper et al. 1977; Kristjánsson 1985a; Eriksson et al. 2014), or only retrieve sites with normal, reverse or transitional VGPs. Researchers can get a quick overview of the data, 


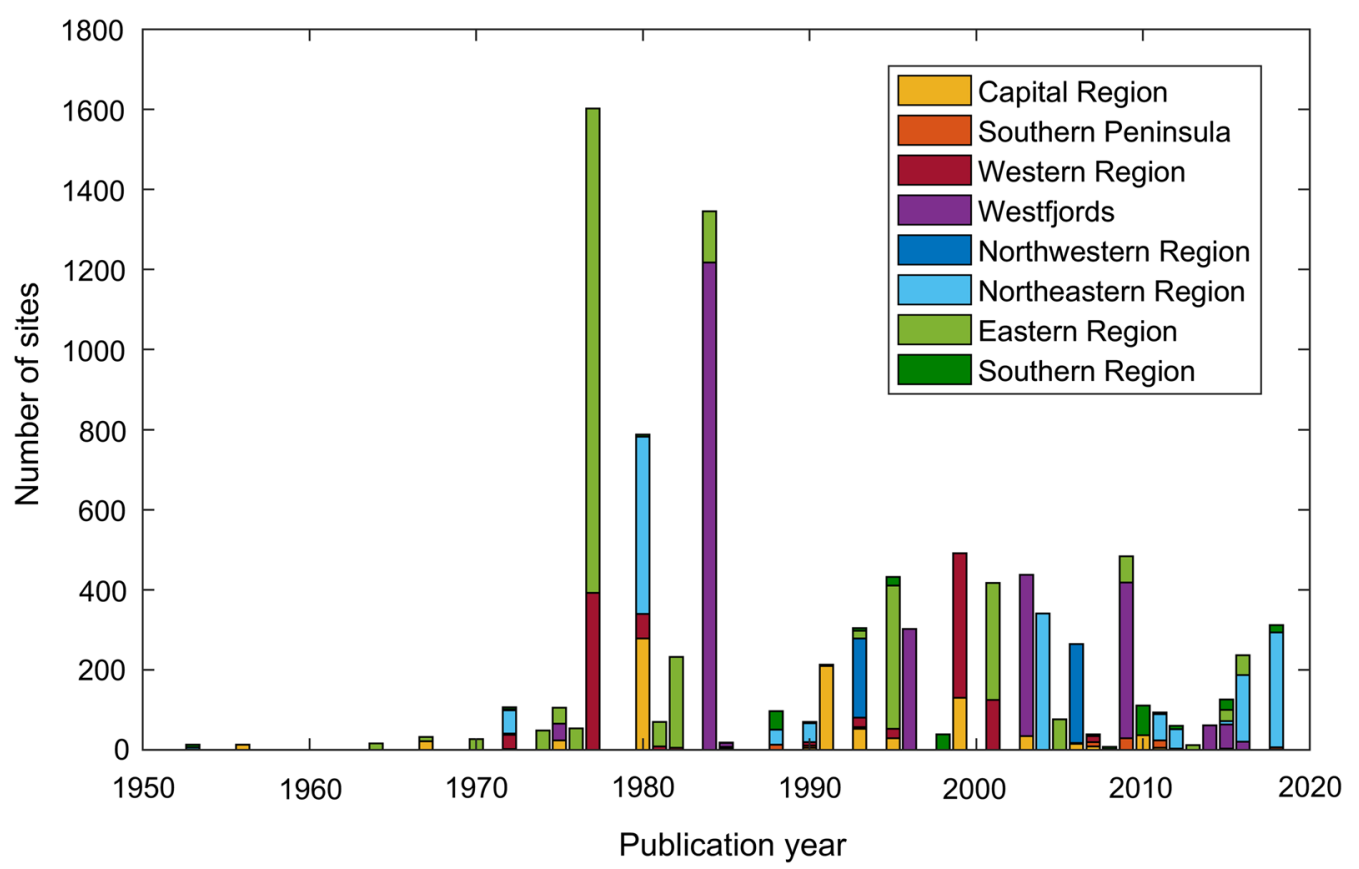

Fig. 6 Histogram of sites by publication year. Distribution of ICEPMAG sites across year of publication, coloured by geographic region (legend inset)

which studies may be relevant, and where the data come from, without having to find and compile each dataset individually.

\section{Results page}

After selecting the constraints and clicking on 'Perform Query', the results page opens in a new window and displays four tabs.

The 'Palaeomagnetic data' tab contains a summary of the query parameters, the main results table, and several relational tables which provide descriptions relevant to the integer ID fields stored in the master table. This tab allows for the user to quickly view the main fields from the data returned in the search. The master table is a truncated version of the full results table which can be downloaded as a CSV file (discussed below). The output to the webpage is limited because of the potential to return and display thousands of site results.

The 'Location map' tab produces an interactive map which plots all sites matching the search terms (e.g. Fig. 4). The map is generated by parsing the results from PHP to the Google Maps Javascript application program interface (API) and allows the user to zoom and navigate around the map to view the site locations. Matching sites are shown as markers over the default map, with options to display underlying terrain or satellite imagery. Hovering over a marker will display the reference and location IDs, which correspond to relational tables displayed underneath the map.
The 'VGP plot' tab displays a plot of all VGP positions contained in the search results. The results are plotted on a Mollweide projection of Earth, centred on the Greenwich meridian (e.g. Fig. 5). The plot is generated by parsing the results to a Python script which generates downloadable PNG and SVG files and allows the user to quickly view VGP data matching the search criteria.

The 'Download data' tab provides a link to a downloadable CSV file which contains the full results of the search. The CSV file contains 70 data fields and allows to user to retrieve and use and the full dataset contained in ICEPMAG.

\section{Database overview}

Locations and ages of palaeomagnetic sites

In general, palaeomagnetic studies in Iceland have targeted areas away from the central spreading ridge and recent glacial and volcanic activity (Fig. 1). Data in ICEPMAG are dominated by a number of large studies published in the 1970s and 1980s (Fig. 6); these studies targeted older lavas in the Westfjords and Eastern Region, with some reporting results from over 1000 lavas each (Watkins and Walker 1977; McDougall et al. 1984). Relatively, few studies have been carried out in the Southern Region, which is prone to frequent seismic and volcanic activity, as well as glacial flooding, and long sequences of lavas are not easily accessible. Recently, a number of studies have targeted Holocene lavas closer to the central ridge and volcanic centres (e.g. Stanton et al. 

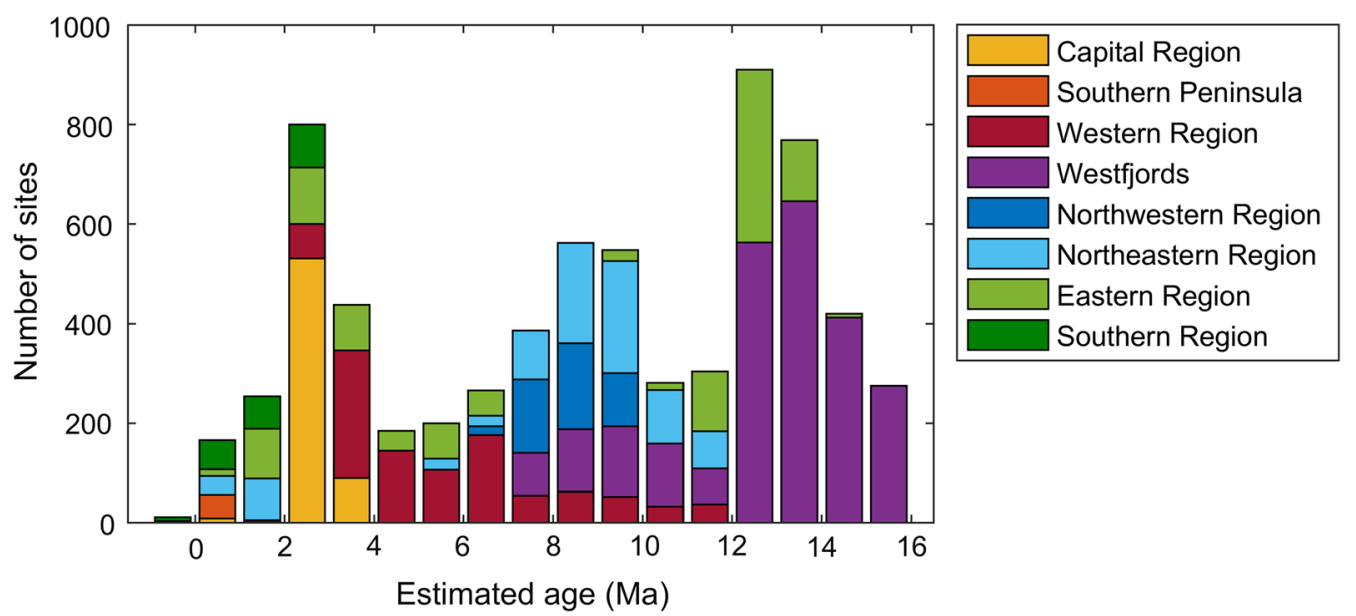

Fig. 7 Histogram of sites by age. Distribution of ICEPMAG sites across the $0-16$ Ma age range, coloured by geographic region (legend inset). Sites with negative values $(<0 \mathrm{Ma})$ indicate lavas erupted since the standard year AD 1950

2011; Tanaka et al. 2012; Cromwell et al. 2015; Pinton et al. 2018).

Sites in ICEPMAG are reasonably distributed across the 0-16 Ma age range (Fig. 7), although the distribution of estimated ages has some peaks due to a number of large studies reporting hundreds of sites each:

- 2-3 Ma (Doell 1972; Kristjánsson et al. 1980, 1991; Helgason and Duncan 2001; Tanaka and Yamamoto 2016)

- 8-10 Ma (Saemundsson et al. 1980; Helgason 1982; McDougall et al. 1984; Kristjánsson and Jóhannesson 1999; Kristjánsson et al. 2006)

- 12-14 Ma (Piper et al. 1977; McDougall et al. 1984; Kristjánsson et al. 1995; Kristjánsson and Jóhannesson 1996; Kristjánsson 2009).

Radiometric (K-Ar and Ar/Ar) dating of lavas is difficult in Iceland, due to a low potassium content (e.g. McDougall et al. 1984; Guillou et al. 2010; Jicha et al. 2011), so most studies have relied on broad magnetostratigraphic controls to constrain age estimates. Relatively, few sites (only 230 or $\sim 2 \%$ ) in ICEPMAG contain precise dating information (Fig. 8), and most of the geological age estimates are published with age uncertainties in the range of $\pm 0.5 \mathrm{Ma}$.

Dating with modern methods (e.g. Camps et al. 2011; Singer 2014) is required to revise and improve precise age estimates, as much of the radiometric work was carried out using the K-Ar method prior to the mid-1980s (e.g. Moorbath et al. 1968; Saemundsson and Noll 1974; McDougall et al. 1976; Saemundsson et al. 1980; Jancin et al. 1985). Methods, standards, and decay constants have changed since that time

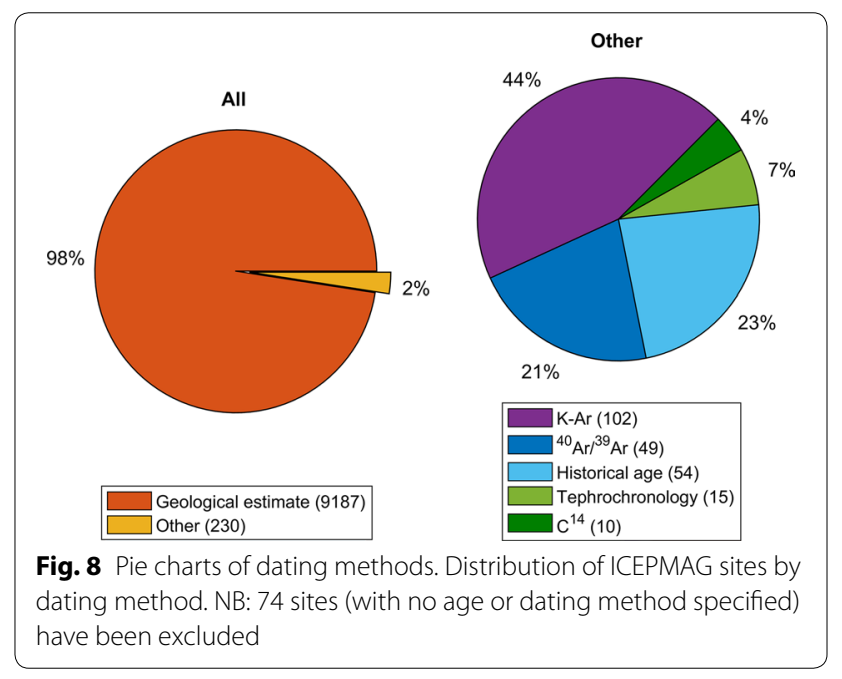

(e.g. Renne 2000; Kuiper et al. 2008; Renne et al. 2010; Rivera et al. 2011), so there is significant potential to refine the age estimates in ICEPMAG, especially with respect to the dating of reversals and excursions (which are the clearest stratigraphic markers), and this may help refine ages in the GPTS.

\section{Directional data}

Typically, the number of samples collected per site has been low (Fig. 9), with $78 \%$ of sites reporting results from four samples or fewer. It has been considered that '...collecting larger numbers of samples per flow is not necessary because of the very good stability of original remanence in Icelandic lavas...' (McDougall et al. 1984). This view is reflected in the distribution of $\alpha_{95}$ values (Fig. 10): nearly half (49\%) of the site mean directions in 


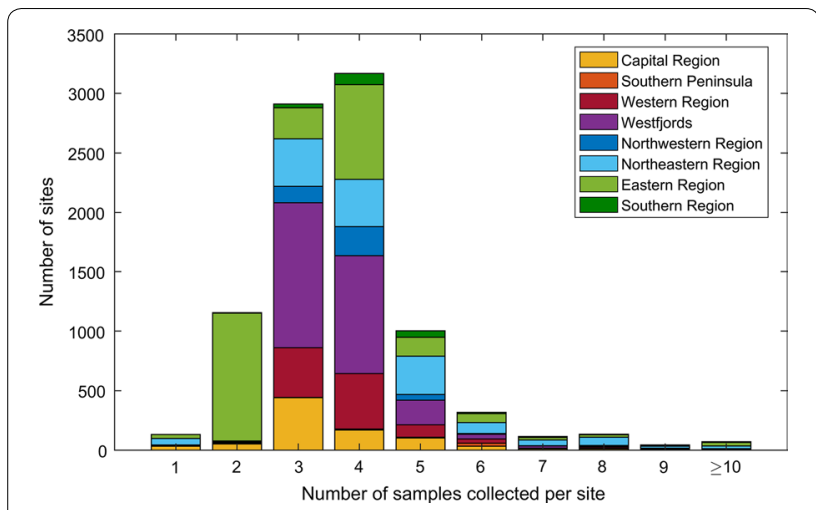

Fig. 9 Histogram of samples collected per site. Distribution of number of samples collected per site, coloured by geographic region (legend inset)

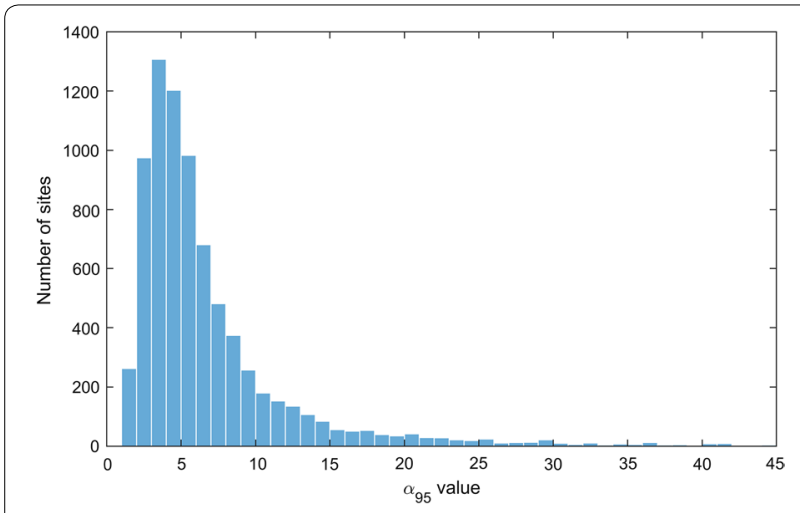

Fig. 10 Histogram of $\alpha_{95}$ values. Distribution of ICEPMAG sites by reported $\alpha_{95}$ value (limited to $<45^{\circ}$ )

ICEPMAG have $\alpha_{95} \leq 5^{\circ}$, and $72 \%$ with $\alpha_{95} \leq 10^{\circ}$. Directions with an $\alpha_{95} \leq 5^{\circ}$ are generally considered 'good', although no set criteria exist and, depending on the research purpose, values up to $15^{\circ}$ could be considered acceptable (see Butler 1992).

McDougall's view is also reflected in the distribution of $k$, the Fisherian dispersion parameter (Fig. 11). For sites in ICEPMAG, $k$ is much less frequently reported than $\alpha_{95}$; only 1224 sites report $k$ values (while 7479 report $\alpha_{95}$ values). $k>50$ has been taken as a parameter for some statistical studies (e.g. Johnson et al. 2008) and it appears that nearly all the Icelandic data would fulfil this; of ICEPMAG sites reporting $k$ values, 94\% (1153 sites) have $k>50$ (Fig. 11). Butler (1992) suggests a minimum acceptable value of $k>30$, and expects 'good' values of $k>$ 100 for fresh volcanic rocks.

Published VGPs, calculated from site mean directions, are reasonably well distributed globally (Fig. 12). Of the sites in ICEPMAG reporting VGP data (8561 in

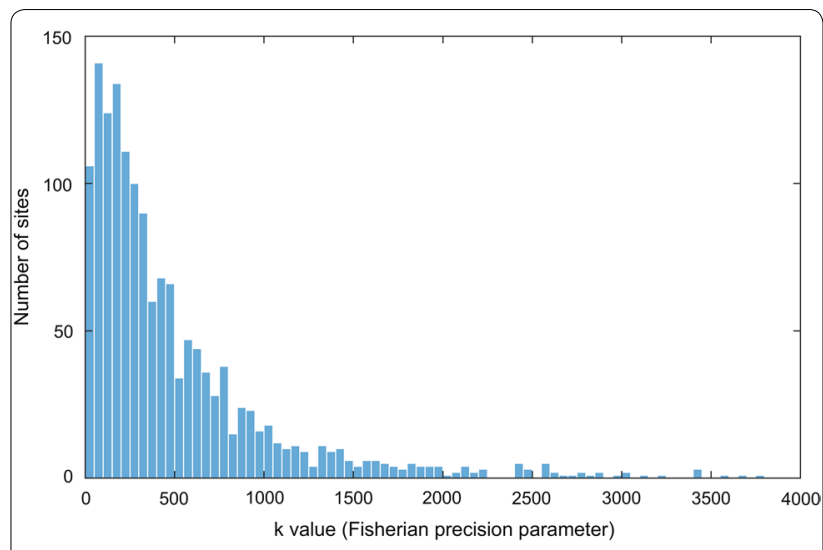

Fig. 11 Histogram of $k$ values. Distribution of ICEPMAG sites by reported $k$ value (limited to $<4000$ )

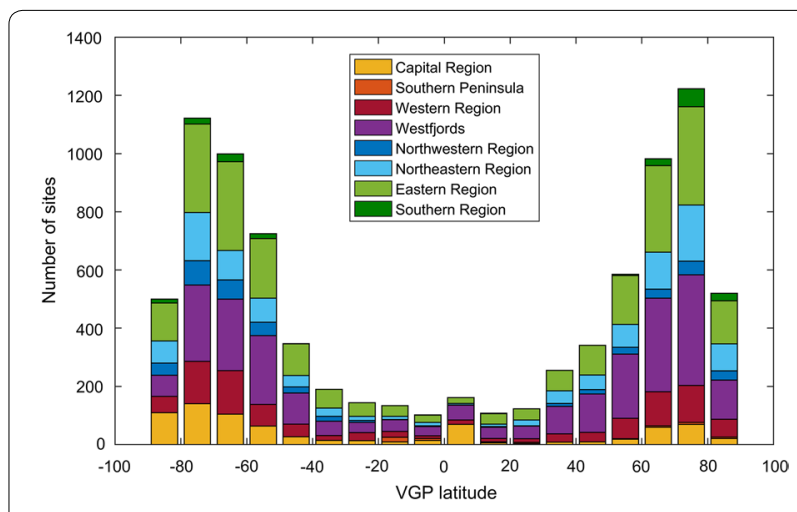

Fig. 12 Histogram of sites by VGP latitude. Distribution of ICEPMAG sites by VGP latitude, coloured by geographic region (legend inset)

total), $42 \%$ and $43 \%$ are designated as normal and reverse polarity, respectively, with $15 \%$ reporting transitional (i.e. VGP latitude $<40^{\circ}$ ) poles. The asymmetry in very low latitudes (i.e. between $10^{\circ} \mathrm{S}$ and $10^{\circ} \mathrm{N}$ ) appears to be a product of extensive sampling of the R3-N3 reversal in southwest Iceland (e.g. Shaw 1975; Kristjánsson and Sigurgeirsson 1993; Goguitchaichvili et al. 1999a) which reports transitional directions biased towards very low northern latitudes (i.e. $0-10^{\circ} \mathrm{N}$ ).

\section{Palaeointensity data}

Figure 13 displays the number of sites in ICEPMAG by palaeointensity method. While Thellier-Thellier-type methods (see below) have been mostly used for palaeointensity studies on Iceland, Shaw-type methods have contributed the largest number of palaeointensity results to ICEPMAG, primarily from two large studies (Shaw et al. 1982; Roberts and Shaw 1984). Studies contributing 


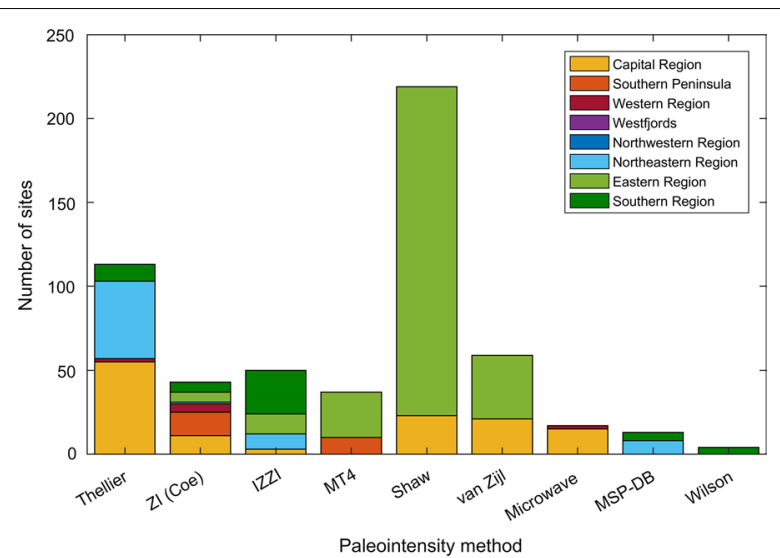

Fig. 13 Histogram of sites by palaeointensity method. Distribution of ICEPMAG sites by palaeointensity method, coloured by geographic region (legend inset)

palaeointensity results to ICEPMAG are listed below without reservation. However, some of the studies contain limited or questionable results, e.g. Kristjánsson (1985b) demonstrated that several data in the two large Shaw-type studies (cited above) are internally inconsistent.

\section{Thellier-Thellier-type methods}

The Thellier-Thellier method in its original form (Thellier and Thellier 1959) has been used by Schweitzer and Soffel (1980), Goguitchaichvili et al. (1999a, b, c), Camps et al. (2011), Stanton et al. (2011), and Tanaka and Yamamoto (2016). The Coe-Thellier (or ' $Z I^{\prime}$ ') variation (Coe 1967) has been used by Senanayake et al. (1982), Marshall et al. (1988), Levi et al. (1990), Tanaka et al. (2012, 1995), and Vérard et al. (2012). More recently, the 'IZZI' variant (Tauxe and Staudigel 2004) has been used by Michalk et al. (2008) and Cromwell et al. (2015). Other studies on Iceland, e.g. Linder and Leonhardt (2009) and Ferk and Leonhardt (2009), have included additional alteration and additivity checks as specified by the 'MT4' method (Leonhardt et al. 2004).

\section{Shaw-type methods}

The use of AF demagnetisation in palaeointensity experiments was initially proposed by van $\mathrm{Zijl}$ et al. (1962) and used on Icelandic lavas in this original form by Smith (1967a, b) and Lawley (1970), and partially by Schweitzer and Soffel (1980). The method was revised and popularised by Shaw (1974) and subsequently used on Icelandic lavas by Shaw (1975), Shaw et al. (1982), Senanayake et al. (1982), and Roberts and Shaw (1984), and recently to a limited extent by Tanaka et al. (2012).

\section{Other methods}

Microwave excitation for demagnetisation, as proposed by Walton et al. (1993), has seen limited use in Iceland by Brown et al. (2006) and Stanton et al. (2011). The 'MSPDB' (Dekkers and Böhnel 2006) method has been trialled on Icelandic lavas by Michalk et al. (2008) and Muxworthy and Taylor (2011). Muxworthy (2010) also trialled the 'Wilson' method (Wilson 1961), as Schweitzer and Soffel (1980) had done previously.

\section{Discussion}

\section{Selection criteria}

There were no reliability criteria enforced in the construction of ICEPMAG. Our knowledge on what constitutes reliable data is always evolving and being reevaluated. The primary aim of the ICEPMAG database is to preserve data that have already been collected and make them available to researchers for whatever application is being pursued. This approach maximises the amount of data available to researchers and allows individuals to refine the dataset based on their own criteria, specific research requirements, and previous observations. A number of reliability criteria have been suggested for various purposes (e.g. McElhinny and McFadden 2000; Johnson et al. 2008; Cromwell et al. 2018), and we encourage the reader to think about the applicability of these criteria when using Icelandic data. There may be uses for the data in ICEPMAG that have not been envisioned and blanket application of such criteria may hinder research in some direction.

\section{Guidelines for data usage}

It is suggested that users of ICEPMAG think critically about the data in the database and how to use them. The query form has been designed for researchers to quickly return data that fit various statistical parameters. The form enables users to get an overview of the content as a whole and remove data from studies that may not fit their needs. Palaeomagnetic data in the database have been collected for different purposes. It would not be advised to include data collected to understand, e.g. the influence of tectonic rotation in northern Iceland (Jancin 2010; Horst et al. 2018; Titus et al. 2018; Young et al. 2018) in statistical analyses of palaeosecular variation. This is a compromise in the construction of the ICEPMAG database.

Before analysing the data, researchers should consider the precision of the data and the level of precision required to solve the problem in question, e.g. palaeomagnetic directions are not more precise than $\pm 1^{\circ}$ in declination and inclination, due to the errors inherent in sampling and measurement processes. Furthermore, the kind of metadata required to ensure the data are fit for 
purpose should also be considered, e.g. whether or not a tilt correction has been applied to the data, how reliable this correction is, and if a regional rather than a local tilt has been applied. These are important to consider when building a dataset for long term field analysis.

\section{Serial correlation}

Another issue with Icelandic data is serial correlation of palaeodirections, or 'oversampling' of the field, where multiple lava sequences have erupted in short-time intervals, potentially leading to inaccurate estimates of PSV and biasing of mean directions (Johnson and McFadden 2015). This is discussed in several papers (e.g. Kristjánsson 2002, 2013). Johnson and Constable (1997) suggested thinning of datasets to address this problem, a method which has been applied to Icelandic data in a number of cases (e.g. Kristjánsson et al. 1980, 2003, 2006). Tests such as a non-random-ordering (NRO) factor can also be performed (e.g. Biggin et al. 2008; Brown et al. 2009) to identify serial correlation.

\section{Future applications of Icelandic data}

Kristjánsson $(2008,2013)$ advocates for further research on large collections of Icelandic lava flows to improve our understanding of the nature of the geomagnetic field. Despite such a large existing collection from the region, still only a small percentage of the exposed sections in Iceland have been sampled for palaeomagnetic purposes. Statistical analyses of data from Icelandic lavas appear to yield several results in contrast to some of those from global datasets and further research may help to address a number of fundamental and long-standing questions in palaeomagnetism, such as whether or not secular variation and polarity reversal rates are related to the magnitude of the dipole moment, reversals follow preferred longitudinal paths and/or are significantly influenced by non-dipolar fields during transitions, and how mean field intensity varies as a function of VGP latitude. Analyses of Icelandic data could also be used to investigate the presence of asymmetries in the normal and reversed palaeomagnetic field (e.g. epoch lengths, field intensities, mean VGPs).

There is significant potential to explore the long-term evolution of geomagnetic field intensity on Iceland. There have been a small number of palaeointensity studies relative to directional studies. Although there are a significant number of palaeodirections from the past $\sim 2 \mathrm{Ma}$, there are not many data from the 500 or so post-glacial lavas on Iceland (directions or intensities) and absolute palaeointensity data in general (although compared with other locations, there are more). To date, no palaeointensity studies have been carried out in the older lavas of northwest Iceland. There is perhaps a greater potential to find unaltered lavas at higher elevations in the Westfjords. Palaeointensity studies on Iceland could also be more fruitful if rocks with more favourable rock magnetic properties are sought, e.g. volcanic glass (Cromwell et al. 2015), rather than the massive parts of lava flows.

Radiometric dating of lavas on Iceland has received little attention since the mid-1980s (see "Locations and ages of palaeomagnetic sites" section). Renewed interest using more modern approaches to, e.g. ${ }^{40} \mathrm{Ar} /{ }^{39} \mathrm{Ar}$ dating, could significantly improve our understanding of the age of palaeomagnetic variations on Iceland, including the age of reversal boundaries, which could aid in refining the GPTS.

\section{Conclusion \\ Summary of outcomes}

Research in Iceland has produced an extensive collection of palaeomagnetic data which has been compiled into ICEPMAG. This new database accompanies other recent efforts to compile large regional datasets and provides a useful tool for palaeomagnetists and other Earth scientists carrying out research in Iceland or looking to utilise Icelandic data. Palaeomagnetic data from 9491 sites with palaeodirections and/or palaeointensity measurements, published across 79 studies between 1953 and 2018, can be easily accessed and downloaded. 8936 contain direction only, 218 intensity only, and 337 both direction and intensity. Each entry in the database contains a significant amount of metadata.

The ICEPMAG database is accessible through a publicly available website (http://www.icepmag.org), which features a simple query form to enable rapid searching and visualisation of Icelandic data. The results from queries are displayed on a separate results page which contains summary tables of the data and calls additional scripting to produce an interactive location map, a VGP plot, and a downloadable spreadsheet containing the full results table.

\section{Path forward}

ICEPMAG will be uploaded to MagIC, contributing an additional 52 studies and 6857 sites to the global palaeomagnetic database.

Subsequent revisions to ICEPMAG are expected to include:

- Addition of new data from the Iceland Palaeomagnetism Laboratory as they are published, as well as new studies from other laboratories.

- Addition of new age data as new geochronological studies are published. 
- Addition of other studies containing data that were not available in tabular form in the published literature.

- Continued long-term maintenance of the database and adaptations based upon the needs of the palaeomagnetic community.

\section{Additional file}

Additional file 1. Additional Tables.

\section{Acknowledgements}

We acknowledge Leó Kristjánsson's immense body of work on the palaeomagnetism of Icelandic lavas (described in the main text). Construction of the database was aided significantly by Leó's digital compilation, which provided data from 5800 sites (Kristjánsson 2013). We thank Leó for providing helpful comments on an earlier draft of the manuscript.

We acknowledge the work of Fabio Donadini, Kimmo Korhonen and Lauri Pesonen who initiated the GEOMAGIA project and developed the principles and coding that this database borrows from heavily. We thank Nick Jarboe for helping us understand the inner workings of MaglC. We thank the two anonymous reviewers whose comments/suggestions helped improve and clarify this manuscript.

\section{Authors' contributions}

MCB conceived the project and provided the GEOMAGIA code used to develop ICEPMAG. JTF compiled all palaeomagnetic data and developed the structure and functionality of the database under the guidance of MCB. The manuscript was written by JTF with contributions from MCB. Both authors read and approved the final manuscript.

\section{Funding}

This project was completed as part of a Master's programme at the University of Iceland Faculty of Earth Sciences and no funding was received.

\section{Availability and requirements}

Project name: ICEPMAG. Project home page: http://icepmag.org/. Operating system(s): Platform and browser independent. Programming language: PHP, SQL, HTML, JavaScript, Python. Other requirements: none. License: none. Any restrictions to use by non-academics: none.

\section{Competing interests}

The authors declare that they have no competing interests.

\section{Author details}

${ }^{1}$ Institute of Earth Sciences, University of Iceland, Sturlugata 7, 101 Reykjavík, Iceland. ${ }^{2}$ Centre for Earth Evolution and Dynamics, University of Oslo, Sem Sælands vei 2A, 0371 Oslo, Norway.

Received: 22 May 2019 Accepted: 15 July 2019

Published online: 30 July 2019

\section{References}

Barton CE (1991) New IAGA data bases established. Eos Trans Am Geophys Union 72(31):332. https://doi.org/10.1029/EO072i031 p00332-01

Biggin AJ, Hinsbergen DJJV, Langereis CG, Straathof GB, Deenen MHL (2008) Geomagnetic secular variation in the Cretaceous Normal Superchron and in the Jurassic. Phys Earth Planet Inter 169:3-19. https://doi. org/10.1016/j.pepi.2008.07.004

Brown MC, Shaw J, Goguitchaichvili AT (2006) Microwave palaeointensity from the R3-N3 geomagnetic field reversal. Geophys J Int 167(1):53-69. https://doi.org/10.1111/j.1365-246X.2006.03034.x
Brown MC, Singer BS, Knudsen MF, Jicha BR, Finnes E, Feinberg JM (2009) No evidence for Brunhes age excursions, Santo Antão, Cape Verde. Earth Planet Sci Lett 287(1-2):100-115. https://doi.org/10.1016/j. epsl.2009.07.039

Brown MC, Donadini F, Korte M, Nilsson A, Korhonen K, Lodge A, Lengyel SN, Constable CG (2015) GEOMAGIA50.v3: 1. general structure and modifications to the archeological and volcanic database. Earth Planets Space 67:83. https://doi.org/10.1186/s40623-015-0232-0

Brynjólfsson A (1957) Studies of remanent magnetism and viscous magnetism in the basalts of Iceland. Adv Phys 6(23):247-254

Butler RF (1992) Paleomagnetism—-magnetic domains to geologic terranes. Blackwell, Boston, p 319

Camps P, Singer BS, Carvallo C, Goguitchaichvili AT, Fanjat G, Allen B (2011) The Kamikatsura event and the Matuyama-Brunhes reversal recorded in lavas from Tjörnes Peninsula, Northern Iceland. Earth Planet Sci Lett 310(1-2):33-44. https://doi.org/10.1016/j.epsl.2011.07.026

Coe RS (1967) The determination of paleo-intensities of the Earth's magnetic field with emphasis on mechanisms which could cause non-ideal behavior in Thellier's method. J Geomagn Geoelectr 19(3):157-179. https://doi.org/10.5636/jgg.19.157

Constable C (2001) Geomagnetic reversals: rates, timescales, preferred paths, statistical models and simulations. In: Jones CA, Soward AM, Zhang K (eds) Earth's core low. Taylor and Francis, London

Cromwell G, Tauxe L, Halldórsson SA (2015) New paleointensity results from rapidly cooled Icelandic lavas: implications for Arctic geomagnetic field strength. J Geophys Res Solid Earth 120:2913-2934. https://doi. org/10.1002/2014JB011828

Cromwell G, Johnson CL, Tauxe L, Constable CG, Jarboe NA (2018) PSV10: a global data set for 0-10 Ma time-averaged field and paleosecular variation studies. Geochem Geophys Geosystems 19(5):1533-1558. https:// doi.org/10.1002/2017GC007318

Dagley P, Wilson RL (1971) Geomagnetic field reversals-a link between strength and orientation of a dipole source. Nat Phys Sci 232:16-19

Dagley P, Wilson RL, Ade-Hall JM, Walker GPL, Haggerty SE, Sigurgeirsson T, Watkins ND, Smith PJ, Edwards J, Grasty RL (1967) Geomagnetic polarity zones for Icelandic lavas. Nature 216:25-29

Dekkers MJ, Böhnel HN (2006) Reliable absolute palaeointensities independent of magnetic domain state. Earth Planet Sci Lett 248(1-2):507-516. https://doi.org/10.1016/j.epsl.2006.05.040

Doell RR (1972) Paleomagnetic studies of Icelandic lava flows. Geophys J R Astron Soc 26:459-479. https://doi.org/10.1111/j.1365-246X.1972.tb057 63.x

Døssing A, Muxworthy AR, Supakulopas R, Riishuus MS, Niocaill CM (2016) High northern geomagnetic field behavior and new constraints on the Gilsá event: Paleomagnetic and 40Ar/39Ar results of 0.5-3.1 Ma basalts from Jökuldalur, Iceland. Earth Planet Sci Lett 456:98-111. https://doi. org/10.1016/j.epsl.2016.09.022

Einarsson T (1957) Magneto-geological mapping in Iceland with the use of a compass. Adv Phys 6:232-239. https://doi.org/10.1080/0001873970 0101591

Eriksson PI, Riishuus MS, Elming S-Å (2014) Magma flow and palaeo-stress deduced from magnetic fabric analysis of the Alftafjorthur dyke swarm: implications for shallow crustal magma transport in Icelandic volcanic systems. Geol Soc London Spec Publ 396:1-26. https://doi.org/10.1144/ SP396.6

Ferk A, Leonhardt R (2009) The Laschamp geomagnetic field excursion recorded in Icelandic lavas. Phys Earth Planet Inter 177(1-2):19-30. https://doi.org/10.1016/j.pepi.2009.07.011

Fisher R (1953) Dispersion on a sphere. Proc R Soc 217:295-305. https://doi. org/10.1098/rspa.1953.0064

Frankel H (1987) Jan Hospers and the rise of paleomagnetism. Eos (Washington, D.C.) 68(24):577-579, 581. https://doi.org/10.1029/HG004p0156

Goguitchaichvili AT, Prévot M, Camps P (1999a) No evidence for strong fields during the R3-N3 Icelandic geomagnetic reversal. Earth Planet Sci Lett 167(1-2):15-34. https://doi.org/10.1016/S0012-821X(99)00010-2

Goguitchaichvili AT, Prévot M, Thompson J, Roberts N (1999b) An attempt to determine the absolute geomagnetic field intensity in Southwestern Iceland during the Gauss-Matuyama reversal. Phys Earth Planet Inter 115(1):53-66. https://doi.org/10.1016/S0031-9201(99)00064-3

Goguitchaichvili AT, Prévot M, Dautria J-M, Bacia M (1999c) Thermodetrital and crystallodetrital magnetization in an Icelandic hyaloclastite. 
J Geophys Res Solid Earth 104(B12):29219-29238. https://doi. org/10.1029/1999JB900260

Guillou H, Van Vliet-Lanoe B, Gudmundsson A, Nomade S (2010) Quaternary geochronology new unspiked K-Ar ages of quaternary sub-glacia and sub-aerial volcanic activity in Iceland. Quat Geochronol 5:10-19. https://doi.org/10.1016/j.quageo.2009.08.007

Helgason J (1982) Magnetostratigrahy of the exposed lava section east of the IRDP drill hole in Reydarfjordur, Eastern Iceland. J Geophys Res 87(B8):6396-6404. https://doi.org/10.1029/JB087iB08p06396

Helgason J, Duncan RA (2001) Glacial-interglacial history of the Skaftafell region, Southeast Iceland, 0-5 Ma. Geology 29(2):179-182

Hicken A (1972) Catalogue of paleomagnetic directions and poles. Department of Energy, Mines and Resources, Ottawa

Horst AJ, Karson JA, Varga RJ (2018) Large rotations of crustal blocks in the Tjörnes fracture zone of Northern Iceland. Tectonics 37(6):1607-1625 https://doi.org/10.1002/2016TC004371

Hospers J (1951) Remanent magnetism of rocks and the history of the geomagnetic field. Nature 168:1111-1112. https://doi.org/10.1038/16811 $11 \mathrm{a} 0$

Hospers J (1953) Palaeomagnetic studies of Icelandic rocks. Ph.D. thesis, University of Cambridge

Irving E, Tancyzk E, Hastie J (1976) Catalogue of paleomagnetic directions and poles, 4th issue, Mesozoic results 1954-1975. Geomagn. Ser., 6, 70 pp. Geomagn. Serv. Ottawa, Canada

Jancin MD (2010) Volcano-tectonic evolution of Flateyjarskagi, North Central Iceland. Ph.D. Thesis, Pennsylvania State University

Jancin MD, Young KD, Voight B (1985) Stratigraphy and K/Ar ages across the west flank of the northeast Iceland axial rift zone, in relation to the $7 \mathrm{Ma}$ volcano-tectonic reorganization of Iceland. J Geophys Res 90(B12):9961-9985

Jarboe NA, Koppers AA, Tauxe L, Minnett R, Constable C (2012) The online MagIC database: data archiving, compilation, and visualization for the geomagnetic, paleomagnetic and rock magnetic communities. Abstr. GP31A-1063 Present. 2012 AGU Fall Meeting

Jicha BR, Kristjánsson L, Brown MC, Singer BS, Beard BL, Johnson CM (2011) New age for the Skálamaelifell excursion and identification of a global geomagnetic event in the late Brunhes chron. Earth Planet Sci Lett 310:509-517. https://doi.org/10.1016/j.epsl.2011.08.007

Jóhannesson H, Sæmundsson K (2009) Geological map of Iceland: Tectonics (1:600000). Náttúrufræðistofnun Íslands, Reykjavík. Retrieved from http://atlas.Imi.is/NI_Data/

Johnson CL, Constable CG (1995) The time-averaged geomagnetic field as recorded by lava flows over the past 5 Myr. Geophys J Int 122(2):489519. https://doi.org/10.1111/j.1365-246X.1995.tb07010.x

Johnson CL, Constable CG (1996) Palaeosecular variation recorded by lava flows over the past five million years. Philos Trans R Soc A Math Phys Eng Sci 354(1704):89-141. https://doi.org/10.1098/rsta.1996.0004

Johnson CL, Constable CG (1997) The time-averaged geomagnetic field: global and regional biases for 0-5 Ma. Geophys J Int 131(3):643-666. https://doi.org/10.1111/j.1365-246X.1997.tb06604.x

Johnson CL, McFadden P (2015) The time-averaged field and paleosecular variation, Chap. 5.11. In: Schubert G (ed) Treatise on geophysics, vol 5, 2nd edn. Elsevier B.V., Oxford, pp 385-417. https://doi.org/10.1016/ B978-0-444-53802-4.00105-6

Johnson CL, Constable CG, Tauxe L, Barendregt R, Brown LL, Coe RS, Layer P, Mejia V, Opdyke ND, Singer BS, Staudigel H, Stone DB (2008) Recent investigations of the $0-5 \mathrm{Ma}$ geomagnetic field recorded by lava flows. Geochemis Geophys Geosyst 9(4):1-31. https://doi. org/10.1029/2007GC001696

Kelly P, Gubbins D (1997) The geomagnetic field over the past 5 million years. Geophys J Int 128(2):315-330. https://doi.org/10.1111/j.1365246X.1997.tb01557.X

Khramov AN (1971) Palaeomagnetic directions and palaeomagnetic poles. Data USSR 1:124

Khramov AN (1976) Paleomagnetic directions and pole positions. In: Data USSR Sov. Geophys. Committee, World Data Cent. B, Moscow, Russia

Koppers A, Tauxe L, Constable C, Pisarevsky S, Jackson M, Solheid P, Banerjee S, Johnson C, Genevey A, Delaney R, Baker P, Sbarbori E (2005) The Magnetics Information Consortium (Mag|C) online database: uploading, searching and visualizing paleomagnetic and rock magnetic data [abs.]. Eos Trans Am Geophys Union supp 86(52):33-0088
Korhonen K, Donadini F, Riisager P, Pesonen LJ (2008) GEOMAGIA50: an archeointensity database with PHP and MySQL. Geochem Geophys Geosyst. https://doi.org/10.1029/2007GC001893

Kristjánsson L (1968) The paleomagnetism and geology of North-Western Iceland. Earth Planet Sci Lett 4:448-450

Kristjánsson L (1982) Palaeomagnetic research on Icelandic rocks—a bibliographical review 1951-1981. Jökull 32:91-106

Kristjánsson L (1985a) Magnetic and thermal effects of dike intrusions in Iceland. J Geophys Res 90(B12):10129. https://doi.org/10.1029/JB090 iB12p10129

Kristjánsson L (1985b) On 'The relationship between the magnitude and direction of the geomagnetic field during the late Tertiary in Eastern Iceland' by N. Roberts and J. Shaw. Geophys J R Astr Soc 80:555-559

Kristjánsson L (1985c) Some statistical properties of palaeomagnetic directions in Icelandic lava flows. Geophys J R Astr Soc 80:57-71

Kristjánsson L (1993) Investigations on geomagnetic reversals in Icelandic lavas, 1953-78. Terra Nov 5(1):6-12. https://doi. org/10.1111/j.1365-3121.1993.tb00220.x

Kristjánsson L (1999) On low-latitude virtual geomagnetic poles in Icelandic basalt lava sequences. Phys Earth Planet Inter 115(2):137-145. https:// doi.org/10.1016/S0031-9201(99)00072-2

Kristjánsson L (2002) Estimating properties of the paleomagnetic field from Icelandic lavas. Phys Chem Earth 27(25-31):1205-1213. https://doi. org/10.1016/S1474-7065(02)00122-5

Kristjánsson L (2008) Paleomagnetic research on Icelandic lava flows. Jökull 58:101-116

Kristjánsson L (2009) A new study of paleomagnetic directions in the Miocene lava pile between Arnarfjörður and Breiðafjörður in the Vestfirðir peninsula, Northwest Iceland. Jökull 59:33-50

Kristjánsson L (2013) Analyses of primary remanence vector data from a large collection of lava flows: towards improved methodology in paleo-geomagnetism. Stud Geophys Geod 57(4):543-564. https://doi. org/10.1007/s11200-012-0480-4

Kristjánsson L (2016) Extension of the Middle Miocene Kleifakot geomagnetic instability event in Extension of the Middle Miocene Kleifakot geomagnetic instability event in Ísafjörður, Northwest Iceland. Jökull 66:83-94

Kristjánsson L, Audunsson H (2007) Um segulstefnu i hraunlögum og óvissu í túlkun hennar (Accuracy of direction of remanent magnetization from lavas in Iceland). Raust 4:17-25

Kristjánsson L, Jóhannesson H (1989) Variable dispersion of Neogene geomagnetic field directions in Iceland. Phys Earth Planet Inter 56:124-132. https://doi.org/10.1016/0031-9201(89)90042-3

Kristjánsson L, Jóhannesson H (1996) Stratigraphy and paleomagnetism of the lava pile south of Ísafjarðardjúp, NW-Iceland. Jökull 44:3-16

Kristjánsson L, Jóhannesson H (1999) Secular variation and reverals in a composite $2.5 \mathrm{~km}$ thick lava section in central Western Iceland. Earth Planets Space 51(4):261-276. https://doi.org/10.1186/BF03352230

Kristjánsson L, Jónsson G (2007) Paleomagnetism and magnetic anomalies in Iceland. J Geodyn 43:30-54. https://doi.org/10.1016/j.jog.2006.09.014

Kristjánsson L, Jónsson G (2017) A total-field magnetic anomaly map of the Reykjanes peninsula, Southwest Iceland. Jökull 67:43-49

Kristjánsson L, McDougall I (1982) Some aspects of the late tertiary geomagnetic-field in Iceland. Geophys J R Astr Soc 68:273-294

Kristjánsson L, Sigurgeirsson M (1993) The R3-N3 and R5-N5 palaeomagnetic transition zones in SW-Iceland revisited. J Geomagn Geoelectr 45:275-288. https://doi.org/10.5636/jgg.45.275

Kristjánsson L, Fridleifsson IB, Watkins ND (1980) Stratigraphy and paleomagnetism of the Esja, Eyrarfjall and Akrafjall Mountains, SW-Iceland. J Geophys 47:31-42

Kristjánsson L, Gudmundsson A, Haraldsson H (1995) Stratigraphy and paleomagnetism of a 3-km-thick Miocene lava pile in the Mjóifördur area, eastern Iceland. Geol Rundschau 84(4):813-830. https://doi. org/10.1007/BF00240570

Kristjánsson L, Jóhannesson H, Fridleifsson IB (1991) Paleomagnetic stratigraphy of the Mosfellssveit area, SW-Iceland: a pilot study. Jökull 41(1):47-60

Kristjánsson L, Hardarson BS, Audunsson H (2003) A detailed palaeomagnetic study of the oldest (15 Myr) lava sequences in Northwest Iceland. Geophys J Int 155(3):991-1005. https://doi.org/10.1111/j.1365246X.2003.02111.x 
Kristjánsson L, Gudmundsson A, Hardarson BS (2004) Stratigraphy and paleomagnetism of a 2.9-km composite lava section in Eyjafjördur, Northern Iceland: A reconnaissance study. Int J Earth Sci 93:582-595. https://doi.org/10.1007/s00531-004-0409-4

Kristjánsson L, Gudmundsson A, Hjartarson A, Hallsteinsson H (2006) A paleomagnetic study of stratigraphic relations in the lava pile of Norðurárdalur and Austurdalur, Skagafïrður, North Iceland. Jökull 56(56):39-56

Kuiper KF, Deino A, Hilgen FJ, Krijgsman W, Renne PR, Wijbrans JR (2008) Synchronizing rock clocks of Earth history. Science 320(5875):500504. https://doi.org/10.1126/science.1154339

Lawley EA (1970) The intensity of the geomagnetic field in Iceland during neogene polarity transitions and systematic deviations. Earth Planet Sci Lett 10(1):145-149. https://doi.org/10.1016/0012-821X(70)90076-2

Leonhardt R, Heunemann C, Krasa D (2004) Analyzing absolute paleointensity determinations: acceptance criteria and the software ThellierTool4.0. Geochem Geophys Geosyst. https://doi.org/10.1029/2004G C000807

Levi S, Audunsson H, Duncan RA, Kristiánsson L, Gillot PY, Jakobsson SP (1990) Late Pleistocene geomagnetic excursion in Icelandic lavas: confirmation of the Laschamp excursion. Earth Planet Sci Lett 96(3-4):443-457. https://doi.org/10.1016/0012-821X(90)90019-T

Linder J, Leonhardt R (2009) Paleomagnetic full vector record of four consecutive Mid Miocene geomagnetic reversals. Phys Earth Planet Inter 177(1-2):88-101. https://doi.org/10.1016/j.pepi.2009.07.013

Love JJ (1998) Paleomagnetic volcanic data and geometric regularity of reversals and excursions. J Geophys Res 103(B6):12435-12452. https:// doi.org/10.1029/97JB03745

Marshall M, Chauvin A, Bonhommet N (1988) Preliminary paleointensity measurements and detailed magnetic analyses of basalts from the Skalamaelifell excursion, Southwest Iceland. J Geophys Res 93(B10):11681-11698

McDougall I, Watkins ND, Walker GPL, Kristjánsson L (1976) Potassium-argon and paleomagnetic analysis of Icelandic lava flows: limits on the age of anomaly. J Geophys Res 81(8):1505-1512. https://doi.org/10.1029/ JB081i008p01505

McDougall I, Kristjánsson L, Saemundsson K (1984) Magnetostratigraphy and geochronology of northwest Iceland. J Geophys Res 89(B8):7029-7060. https://doi.org/10.1029/JB089iB08p07029

McElhinny MW, Cowley J (1977) Paleomagnetic directions and pole positions. Geophys J R Astr Soc 49:313-356. https://doi.org/10.1111/j.1365246X.1977.tb03712.X

McElhinny MW, Lock J (1991) Global paleomagnetic data base complete. Eos Trans Am Geophys Union 72(51):579

McElhinny MW, Lock J (1996) IAGA paleomagnetic databases with Access. Surv Geophys 17(5):575-591

McElhinny MW, McFadden PL (1997) Palaeosecular variation over the past 5 Myr based on a new generalized database. Geophys J Int 131(2):240252. https://doi.org/10.1016/j.expthermflusci.2014.08.001

McElhinny MW, McFadden PL (2000) Paleomagnetism: continents and oceans. Elsevier, Amsterdam, p 383. https://doi.org/10.1029/2002EO000156

Merrill RT, McElhinny MW (1983) The Earth's magnetic field: its history, origin and planetary perspective. Academic Press, London

Michalk DM, Muxworthy AR, Böhnel HN, Maclennan J, Nowaczyk N (2008) Evaluation of the multispecimen parallel differential pTRM method: a test on historical lavas from Iceland and Mexico. Geophys J Int 173(2):409-420. https://doi.org/10.1111/j.1365-246X.2008.03740.x

Moorbath S, Sigurdsson H, Goodwin R (1968) KAr ages of the oldest exposed rocks in Iceland. Earth Planet Sci Lett 4(3):197-205. https://doi. org/10.1016/0012-821X(68)90035-6

Muxworthy AR (2010) Revisiting a domain-state independent method of palaeointensity determination. Phys Earth Planet Inter 179(1-2):21-31. https://doi.org/10.1016/j.pepi.2010.01.003

Muxworthy AR, Taylor SN (2011) Evaluation of the domain-state corrected multiple-specimen absolute palaeointensity protocol: a test of historical lavas from Iceland. Geophys J Int 187(1):118-127. https://doi. org/10.1111/j.1365-246X.2011.05163.x

Ogg JG (2012) Geomagnetic polarity time scale. In: Gradstein FM, Ogg JG, Schmitz MD, Ogg GM (eds) The Geologic Time Scale. Elsevier, pp 85-113. https://doi.org/10.1016/B978-0-444-59425-9.00005-6
Perrin M, Schnepp E (2004) IAGA paleointensity database: distribution and quality of the data set. Phys Earth Planet Inter 147:255-267. https://doi. org/10.1016/j.pepi.2004.06.005

Pesonen LJ, Torsvik TH (1989) The Fennoscandian paleomagnetic database: compilation of paleomagnetic directions and poles from the northern segment of the EGT. In: Freeman, R., Müller, S. (eds) Proc. sixth work. Eur. Geotraverse Proj. Data Compil. Synop. Interpret., pp 389-399. European Science Foundation, Strasbourg, France

Pinton A, Giordano G, Speranza F, Thordarson T (2018) Paleomagnetism of Holocene lava flows from the Reykjanes Peninsula and the Tungnaá lava sequence (Iceland): implications for flow correlation and ages. Bull Volcanol. https://doi.org/10.1007/s00445-017-1187-8

Piper JDA, Fowler MG, Gibson IL (1977) Dyke magnetization, magnetostratigraphy and upper-crustal structure in the Reydarfordur area of eastern Iceland. Tectonophysics 40(3-4):227-244. https://doi.org/10.1016/00401951(77)90067-1

Pisarevsky S (2005) New edition of the Global Paleomagnetic Database. Eos Trans AGU 86(17):170. https://doi.org/10.1029/2005EO170004

Pisarevsky S, Li Z-X, Wu L (2018) Development of the Global Paleomagnetic Database and new global paleogeographic animation for the last 2 Gy. In: Abstr. GP13A-28 Present. 2018 AGU Fall Meet. Washington, D.C., 10-14 December. AGU, Washington

Quidelleur X, Valet J-P, Courtillot V, Hulot G (1994) Long-term geometry of the geomagnetic field for the last five million years: an updated secular variation database. Geophys Res Lett 21(15):1639-1642. https://doi. org/10.1029/94GL01105

Renne PR (2000) K-Ar and 40Ar/39Ar dating. In: Noller JS, Sowers JM, Lettis WR (eds) Quaternary geochronology: methods and applications. American Geophysical Union. https://doi.org/10.1029/RF004p0077

Renne PR, Mundil R, Balco G, Min K, Ludwig KR (2010) Joint determination of $40 \mathrm{~K}$ decay constants and $40 \mathrm{Ar}^{*} / 40 \mathrm{~K}$ for the Fish Canyon sanidine standard, and improved accuracy for $40 \mathrm{Ar} / 39 \mathrm{Ar}$ geochronology. Geochim Cosmochim Acta 74(18):5349-5367. https://doi.org/10.1016/j. gca.2010.06.017

Rivera TA, Storey M, Zeeden C, Hilgen FJ, Kuiper K (2011) A refined astronomically calibrated 40Ar/39Ar age for Fish Canyon sanidine. Earth Planet Sci Lett 311(3-4):420-426. https://doi.org/10.1016/j.epsl.2011.09.017

Roberts N, Shaw J (1984) The relationship between the magnitude and direction of the geomagnetic field during the Late Tertiary in Eastern Iceland. Geophys J R Astron Soc 76(3):637-651. https://doi.org/10.1111/ j.1365-246X.1984.tb01913.X

Saemundsson K, Noll H (1974) K-Ar ages of rocks from Husafell, western Iceland, and the development of the Husafell Central Volcano. Jökull 24:40-59

Saemundsson K, McDougall I, Watkins ND (1980) K-Ar dating, geological and paleomagnetic study of a 5-km lava succession in Northern Iceland. J Geophys Res 85(B7):3628-3646. https://doi.org/10.1029/JB085iB07p 03628

Schweitzer C, Soffel H (1980) Palaeointensity measurements on postglacial lavas from Iceland. J Geophys 47:57-60

Senanayake WE, McElhinny MW, McFadden PL (1982) Comparison between the Thelliers'and Shaw's palaeointensity methods using basalts less than 5 million years old. J Geomagn Geoelectr 34:141-161. https://doi. org/10.5636/jgg.34.141

Shaw J (1974) A new method of determining the magnitude of the paleomanetic field application to five historic lavas and five archeological samples. Geophys J R Astron Soc 39:133-141

Shaw J (1975) Strong geomagnetic fields during a single Icelandic polarity transition. Geophys J R Astron Soc 40(3):345-350. https://doi. org/10.1111/j.1365-246X.1975.tb04136.x

Shaw J, Dagley P, Mussett M (1982) The magnitude of the palaeomagnetic field in Iceland between 2 and 6 Myr ago. Geophys J R Astron Soc 68(1):211-218. https://doi.org/10.1111/j.1365-246X.1982.tb06970.x

Sigurgeirsson T (1957) Direction of magnetization in Icelandic basalts. Adv Phys 22:240-247. https://doi.org/10.1080/00018739700101601

Singer BS (2014) A quaternary geomagnetic instability time scale. Quat Geochronol 21(1):29-52. https://doi.org/10.1016/j.quageo.2013.10.003

Smith PJ (1967a) On the suitability of igneous rocks for ancient geomagnetic field intensity determination. Earth Planet Sci Lett 2:99-105 
Smith PJ (1967b) The intensity of the tertiary geomagnetic field. Geophys J R Astron Soc 12(3):239-258. https://doi.org/10.1111/j.1365-246X.1967. tb03120.x

Stanton T, Riisager P, Knudsen MF, Thordarson T (2011) New palaeointensity data from Holocene Icelandic lavas. Phys Earth Planet Inter 186(1-2):110. https://doi.org/10.1016/j.pepi.2011.01.006

Suttie N, Biggin A, Holme R (2015) Robust estimators of palaeosecular variation. Geophys J Int 200(2):1046-1051. https://doi.org/10.1093/gji/ ggu443

Tanaka H, Kono M (1994) Paleointensity database provides new resource [Geomagnetism \& Paleomagnetism Section News]. Eos (Washington. DC). https://doi.org/10.1029/94EO02003

Tanaka H, Yamamoto Y (2016) Palaeointensities from Pliocene lava sequences in Iceland: emphasis on the problem of Arai plot with two linear segments. Geophys J Int 205:694-714. https://doi.org/10.1093/gji/ggw031

Tanaka H, Kono M, Kaneko S (1995) Paleosecular variation of direction and intensity from two Pliocene-Pleistocene lava sections in southwestern Iceland. J Geomagn Geoelectr 47:89-102

Tanaka H, Hashimoto Y, Morita N (2012) Palaeointensity determinations from historical and Holocene basalt lavas in Iceland. Geophys J Int 189(2):833-845. https://doi.org/10.1111/j.1365-246X.2012.05412.x

Tauxe L, Staudigel H (2004) Strength of the geomagnetic field in the cretaceous normal superchron: New data from submarine basaltic glass of the Troodos Ophiolite. Geochem Geophys Geosyst. https://doi. org/10.1029/2003GC000635

Tauxe L, Constable C, Koppers A (2003) Current status and future plans for the paleomagnetic database. Geol Soc Am Seattle Annu Meet 35(6):365

Tauxe L, Shaar R, Jonestrask L, Swanson-Hysell NL, Minnett R, Koppers AAP, Constable CG, Jarboe N, Gaastra K, Fairchild L (2016) PmagPy: Software package for paleomagnetic data analysis and a bridge to the Magnetics Information Consortium (MaglC) Database. Geochem Geophys Geosyst 17(6):2450-2463. https://doi.org/10.1002/2016GC006307. arXiv :1605.08479

Thellier E, Thellier O (1959) Sur l'intensité du champ magnétique terrestre dans le passé historique et géologique. Ann Géophysique 15:285

Titus SJ, Chapman W, Horst AJ, Brown M, Davis JR (2018) Distributed deformation in an oceanic transform system: applying statistical tools to structural and paleomagnetic data near the Húsavík-Flatey Fault, Northern Iceland. Tectonics 37:1-14. https://doi.org/10.1029/2018TC005096
Udagawa S, Kitagawa H, Gudmundsson A, Hiroi O, Koyaguchi T, Tanaka H, Kristjánsson L, Kono M (1999) Age and magnetism of lavas in Jökuldalur area, Eastern Iceland: Gilsá event revisited. Phys Earth Planet Inter 115:147-171. https://doi.org/10.1016/S0031-9201(99)00073-4

van Zijl JSV, Graham KWT, Hales AL (1962) The palaeomagnetism of the stormberg Lavas, II. The behaviour of the magnetic field during a reversal. Geophys J R Astron Soc 7(2):169-182. https://doi.org/10.1111/j.1365246X.1962.tb00366.x

Vérard C, Leonhardt R, Winklhofer M, Fabian K (2012) Variations of magnetic properties in thin lava flow profiles: implications for the recording of the Laschamp Excursion. Phys Earth Planet Inter 200-201:10-27. https ://doi.org/10.1016/j.pepi.2012.03.012

Walton D, Share J, Rolph TC, Shaw J (1993) Microwave magnetisation. Geophys Res Lett 20(2):109-111. https://doi.org/10.1029/92GL02782

Watkins ND, Walker GPL (1977) Magnetostratigraphy of eastern Iceland. Am J Sci 277(5):513-584. https://doi.org/10.2475/ajs.277.5.513

Watkins ND, McDougall I, Kristjánsson L (1977) Upper Miocene and Pliocene geomagnetic secular variation in the Borgarfördur area of Western Iceland. Geophys J Int 49(3):609-632. https://doi.org/10.1111/j.1365246X.1977.tb01307.x

Wilson RL (1961) The thermal demagnetization of natural magnetic moments in rocks. Geophys J R Astron Soc 5(1):45-58. https://doi.org/10.1111/ j.1365-246X.1961.tb02928.x

Wilson RL, Dagley P, McCormack AG (1972) Palaeomagnetic evidence about the source of the geomagnetic field. Geophys J R Astr Soc 28:213-224

Young KD, Orkan N, Jancin MD, Saemundsson K, Voight B (2018) Major tectonic rotation along an oceanic transform zone, northern Iceland: evidence from field and paleomagnetic investigations. J Volcanol Geotherm Res. https://doi.org/10.1016/j.jvolgeores.2018.11.020

\section{Publisher's Note}

Springer Nature remains neutral with regard to jurisdictional claims in published maps and institutional affiliations.

\section{Submit your manuscript to a SpringerOpen ${ }^{\circ}$ journal and benefit from:}

- Convenient online submission

- Rigorous peer review

- Open access: articles freely available online

- High visibility within the field

- Retaining the copyright to your article

Submit your next manuscript at $\boldsymbol{\nabla}$ springeropen.com 